\title{
Synoptic evaluation of carbon cycling in the Beaufort Sea during summer: contrasting river inputs, ecosystem metabolism and air-sea $\mathrm{CO}_{2}$ fluxes
}

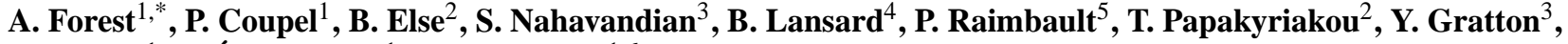 \\ L. Fortier ${ }^{1}$, J.-É. Tremblay ${ }^{1}$, and M. Babin ${ }^{1,6}$ \\ ${ }^{1}$ Takuvik Joint International Laboratory, Université Laval (Canada) - CNRS (France), Département de Biologie and \\ Québec-Océan, Université Laval, Québec, G1V 0A6, Canada \\ ${ }^{2}$ Centre for Earth Observation Science, University of Manitoba, Winnipeg, R3T 2N2, Canada \\ ${ }^{3}$ Institut National de la Recherche Scientifique - Eau Terre Environnement, Québec, G1K 9A9, Canada \\ ${ }^{4}$ Laboratoire des Sciences du Climat et de 1'Environnement, IPSL-CEA-CNRS-Université de Versailles Saint-Quentin, \\ 91198, Gif-sur-Yvette, France \\ ${ }^{5}$ Aix-Marseille Univ., Mediterranean Institute of Oceanography (MIO), UMR7294, CNRS/INSU, UMR235, IRD, 13288, \\ Marseille, CEDEX 09, Université du Sud Toulon-Var (MIO), 83957, La Garde CEDEX, France \\ ${ }^{6}$ Laboratoire d'Océanographie de Villefranche, Université Pierre et Marie Curie (adjunct professor), 06238 \\ Villefranche-sur-Mer Cedex, France \\ *now at: Golder Associates Ltd. 200-1170 boul Lebourgneuf, Québec, G2K 2E3, Canada
}

Correspondence to: A. Forest (alexandre_forest@golder.com)

Received: 5 August 2013 - Published in Biogeosciences Discuss.: 7 October 2013

Revised: 17 March 2014 - Accepted: 3 April 2014 - Published: 27 May 2014

\begin{abstract}
The accelerated decline in Arctic sea ice and an ongoing trend toward more energetic atmospheric and oceanic forcings are modifying carbon cycling in the Arctic Ocean. A critical issue is to understand how net community production (NCP; the balance between gross primary production and community respiration) responds to changes and modulates air-sea $\mathrm{CO}_{2}$ fluxes. Using data collected as part of the ArcticNet-Malina 2009 expedition in the southeastern Beaufort Sea (Arctic Ocean), we synthesize information on sea ice, wind, river, water column properties, metabolism of the planktonic food web, organic carbon fluxes and pools, as well as air-sea $\mathrm{CO}_{2}$ exchange, with the aim of documenting the ecosystem response to environmental changes. Data were analyzed to develop a non-steady-state carbon budget and an assessment of NCP against air-sea $\mathrm{CO}_{2}$ fluxes. During the field campaign, the mean wind field was a mild upwellingfavorable wind $\left(\sim 5 \mathrm{~km} \mathrm{~h}^{-1}\right)$ from the NE. A decaying ice cover ( $<80 \%$ concentration) was observed beyond the shelf, the latter being fully exposed to the atmosphere. We detected some areas where the surface mixed layer was net autotrophic owing to high rates of primary produc-
\end{abstract}

tion (PP), but the ecosystem was overall net heterotrophic. The region acted nonetheless as a sink for atmospheric $\mathrm{CO}_{2}$, with an uptake rate of $-2.0 \pm 3.3 \mathrm{mmol} \mathrm{C} \mathrm{m}^{-2} \mathrm{~d}^{-1}$ (mean \pm standard deviation associated with spatial variability). We attribute this discrepancy to (1) elevated PP rates (>600 $\mathrm{mg} \mathrm{C} \mathrm{m}^{-2} \mathrm{~d}^{-1}$ ) over the shelf prior to our survey, (2) freshwater dilution by river runoff and ice melt, and (3) the presence of cold surface waters offshore. Only the Mackenzie River delta and localized shelf areas directly affected by upwelling were identified as substantial sources of $\mathrm{CO}_{2}$ to the atmosphere $\left(>10 \mathrm{mmol} \mathrm{C} \mathrm{m}^{-2} \mathrm{~d}^{-1}\right)$. Daily $\mathrm{PP}$ rates were generally $<100 \mathrm{mg} \mathrm{C} \mathrm{m}^{-2} \mathrm{~d}^{-1}$ and cumulated to a total PP of $\sim 437.6 \times 10^{3} \mathrm{tC}$ for the region over a 35-day period. This amount was about twice the organic carbon delivery by river inputs $\left(\sim 241.2 \times 10^{3} \mathrm{tC}\right)$. Subsurface PP represented $37.4 \%$ of total PP for the whole area and as much as $\sim 72.0 \%$ seaward of the shelf break. In the upper $100 \mathrm{~m}$, bacteria dominated (54\%) total community respiration $\left(\sim 250 \mathrm{mg} \mathrm{C} \mathrm{m}^{-2} \mathrm{~d}^{-1}\right)$, whereas protozoans, metazoans, and benthos, contributed to 24,10 , and $12 \%$, respectively. The range of production-to-biomass 
ratios of bacteria was wide $\left(1-27 \% \mathrm{~d}^{-1}\right)$, while we estimated a narrower range for protozoans $\left(6-11 \% \mathrm{~d}^{-1}\right)$ and metazoans $\left(1-3 \% \mathrm{~d}^{-1}\right)$. Over the shelf, benthic biomass was twofold $\left(\sim 5.9 \mathrm{~g} \mathrm{C} \mathrm{m}^{-2}\right)$ the biomass of pelagic heterotrophs $\left(\sim 2.4 \mathrm{~g} \mathrm{C} \mathrm{m}^{-2}\right)$, in accord with high vertical carbon fluxes on the shelf (956 $\left.\pm 129 \mathrm{mg} \mathrm{C} \mathrm{m}^{-2} \mathrm{~d}^{-1}\right)$. Threshold PP (PP at which NCP becomes positive) in the surface layer oscillated from 20 to $152 \mathrm{mg} \mathrm{C} \mathrm{m}^{-2} \mathrm{~d}^{-1}$, with a pattern from low-tohigh values as the distance from the Mackenzie River decreased. We conclude that (1) climate change is exacerbating the already extreme biological gradient across the Beaufort shelf-basin system; (2) the Mackenzie Shelf acts as a weak sink for atmospheric $\mathrm{CO}_{2}$, suggesting that PP might exceed the respiration of terrigenous and marine organic matter in the surface layer; and (3) shelf break upwelling can transfer $\mathrm{CO}_{2}$ to the atmosphere, but $\mathrm{CO}_{2}$ outgassing can be attenuated if nutrients brought also by upwelling support diatom production. Our study underscores that cross-shelf exchange of waters, nutrients and particles is a key mechanism that needs to be properly monitored as the Arctic transits to a new state.

\section{Introduction}

As the seasonal ice zone (SIZ) expands with the ongoing retreat in summer ice (Parkinson and Comiso, 2013), increased transport of water, solutes and particles is expected across the Arctic shelf break (Carmack and Chapman, 2003; Forest et al., 2007; Anderson et al., 2010). This is because sea ice and newly opened waters are both exposed to a more dynamic atmospheric forcing, which is a collateral effect of the amplified warming taking place at high northern latitudes (Francis and Vavrus, 2012). The synergy between a fractured, more mobile, sea ice cover and the development of large areas devoid of sea ice creates the ideal pre-conditioning for increased cross-shelf exchange (e.g., O'Brien et al., 2011; Janout et al., 2013). The trend in atmospheric circulation over the Arctic since the late 1990s is an acceleration of the anticyclonic (clockwise) regime (Ogi and Rigor, 2013), recently exacerbated (since $\sim 2006-2007$ ) by a marked intensification of the Beaufort Sea High (a prominent feature of high sea-level pressure) in early summer, which now frequently extends from northern North America to over Greenland (Overland et al., 2012; Moore, 2012). This intensification has translated into an increase in downward Ekman pumping in the Beaufort Gyre and stronger geostrophic currents on its periphery (McPhee, 2013). Although the cyclonic (anticlockwise) regime is apparently in a declining trend in the Arctic during summer (Moore, 2012), coastal storminess is increasing (Vermaire et al., 2013) and the late summer season is affected by a significant rise in the strength and size of cyclones (Simmonds and Keay, 2009). This trend in late summer storm activity apparently culminated in 2012 with the development of the so-called great Arctic cyclone (Sim- monds and Rudeva, 2012; Zhang et al., 2013). As a result, stronger winds induced by both intensified high-pressure systems and large-scale storms increase the potential for momentum transfer and facilitate cross-shelf exchange during and around the period of minimum sea ice.

A prime consequence of increased lateral cross-shelf exchange for ecosystem function and biogeochemical cycling in the Arctic is the upwelling of nutrient-rich and $\mathrm{CO}_{2}$ rich (acidic) halocline waters $(>100 \mathrm{~m}$ ) along the continental slope and over shallow shelves. On the one hand, upwelled nutrients sustain high primary production and associated vertical carbon export, thus resulting in the uptake of $\mathrm{CO}_{2}$ by the surface biota and its subsequent storage at depth through the biological pump (e.g., Anderson et al., 2010; Tremblay et al., 2011). This process is, however, tightly linked to the structure of the pelagic food web, which dictates the pathways of biogenic carbon flow in the water column (Forest et al., 2011). For example, a large biomass of microbial and/or metazoan heterotrophs in the surface layer could possibly negate the potential for $\mathrm{CO}_{2}$ uptake if respiration exceeds primary production (e.g., Ortega-Retuerta et al., 2012). But if the respiration occurs below the mixed layer instead, such as when animals migrate to depth during the day or at the end of summer, heterotrophic respiration might actually contribute to $\mathrm{CO}_{2}$ storage in deeper waters (e.g., Darnis and Fortier, 2012; Kobari et al., 2013). On the other hand, upwelling brings upward acidic waters supersaturated in $\mathrm{CO}_{2}$ with respect to the atmosphere (up to $>600 \mathrm{ppm}$ ), promoting $\mathrm{CO}_{2}$ outgassing and possibly impairing pelagic and benthic organisms sensitive to low pH (Yamamoto-Kawai et al., 2009; Mathis et al., 2012). These phenomena can be particularly strong in the Pacific sector of the Arctic Ocean where a water layer of Pacific origin containing ca. twice as much $\mathrm{CO}_{2}$ as the deep Atlantic water mass lies at intermediate depths (see Lansard et al. 2012 for details).

Analyzing the interplay between hydrodynamics and ecosystem metabolism is a critical task if the implications of increased cross-shelf exchange for ocean acidification and $\mathrm{CO}_{2}$ sink-source balance are to be understood. Despite being utterly needed, such analysis is challenging to realize, as a synoptic view of physical forcings, geochemical setting, and planktonic food web structure is logistically difficult to obtain - especially for the Arctic marine environment. Such evaluation is also complexified by the multiple timescales affecting the environmental and biological factors that govern carbon flux dynamics. Ecosystem metabolic balance can be simplified as the net result of carbon fixation by autotrophic organisms minus that used by the whole biological community for respiration, which encompasses numerous processes in between (e.g., trophic transfer, reproduction, somatic maintenance, motility). However, studies on ecosystem metabolism rarely go beyond the quantification of organic carbon production vs. remineralization, so the phenology of production vs. respiration, the food web components at play, 
and the implications for air-sea $\mathrm{CO}_{2}$ exchange often remain unexplored.

Here we synthesize information on atmospheric and hydrographic forcings, biogeochemical context, plankton metabolism, and air-sea $\mathrm{CO}_{2}$ fluxes, as measured during the ArcticNet-Malina campaign that took place in July-August 2009 across the Mackenzie Shelf region (southeastern Beaufort Sea, Arctic Ocean). This spatial-temporal window was particularly relevant to investigate the potential effects of changing atmospheric and sea ice patterns on the Arctic marine ecosystem. Over that period, the Beaufort Sea was influenced by a shift from a high-pressure system fostering clear sky and strong northerly winds to a more cyclonic regime that promoted clouds and ice melt across the area (NSIDC, 2009). Our objective is to evaluate quantitatively the different fluxes and reservoirs of carbon across the shelf-basin interface to identify key indices of ecosystem response to climate change. Hence, we pose three questions that will support concluding on the potential interactions and feedbacks between ecological and biogeochemical processes with respect to carbon fluxes in the future Arctic Ocean: (1) to what extent was net ecosystem metabolism coupled with sea-to-air $\mathrm{CO}_{2}$ fluxes? (2) What were the roles of cross-shelf exchange, river inputs and sea ice in driving carbon fluxes? (3) How did the planktonic food web respond and feed back to organic and inorganic carbon cycling?

\section{Material and methods}

\subsection{Study area and sampling strategy}

The Mackenzie Shelf in the southeastern Beaufort Sea is a narrow rectangular shelf $(120 \mathrm{~km}$ width $\times 530 \mathrm{~km}$ length $)$ bordered by the Alaskan Beaufort Shelf to the west, the Amundsen Gulf to the east, and by the Canada Basin to the north (Fig. 1). Galley et al. (2013) reviewed the atmospheric and sea ice conditions of the southern Beaufort Sea from 1996 to 2010. Over that period, ocean currents and sea ice circulation patterns were closely coupled, showing an anomalous anti-cyclonic pattern associated with an accentuated Beaufort Sea High when compared with the mean over 1981-2010 (Overland, 2009). The Beaufort Sea High was particularly strong in 2007, when Arctic sea ice extent dramatically declined to $4.1 \times 10^{6} \mathrm{~km}^{2}$. Although less developed, a similar atmospheric pattern prevailed in summer 2008 and for most of summer 2009 (i.e., until August; NSIDC, 2009). Sea ice in the southern Beaufort Sea typically reaches a maximum thickness of $\sim 2-3 \mathrm{~m}$ in March-April and is usually melted by mid-September (Barber and Hanesiak, 2004). In April 2009, Haas et al. (2010) surveyed sea ice thicknesses in the region and found a wide range of conditions, from a multi-year sea ice cover of $2.3-3.3 \mathrm{~m}$ advected south by the anti-cyclonic motion of the Beaufort Gyre, to a thin first-year ice of $1.1 \mathrm{~m}$ northwest of the Mackenzie Canyon.

Despite being the fourth largest river input in terms of freshwater discharge $\left(330 \mathrm{~km}^{3} \mathrm{yr}^{-1}\right)$, the Mackenzie River ranks first for sediment load among Arctic rivers, with an annual mean of $124 \times 10^{6} \mathrm{tyr}^{-1}$ (Gordeev, 2006). In 2009, the water discharge from the Mackenzie was above the mean of 1998-2008 from May to July $(\sim 20.5$ vs. $\left.\sim 17.4 \times 10^{3} \mathrm{~m}^{3} \mathrm{~s}^{-1}\right)$ as well as during September-October $\left(\sim 12.8\right.$ vs. $\left.\sim 10.5 \times 10^{3} \mathrm{~m}^{3} \mathrm{~s}^{-1}\right)$, but was near the average in August (Forest et al., 2013). Typically in summer, ice melt and river runoff generate a stratified surface layer in the top 5-10 $\mathrm{m}$ of the water column (Carmack and Macdonald, 2002). Water masses in the region come from various sources and comprise sea ice meltwater, the Mackenzie River, the polar mixed layer (above $\sim 50 \mathrm{~m}$ ), summer and winter water of Pacific origin $(\sim 50-200 \mathrm{~m})$, Atlantic Water $(\sim 200-800 \mathrm{~m})$, and Canada Basin deep water (>800 m depth) (Lansard et al., 2012). Ocean circulation is complex and driven by wind and sea ice dynamics. Northwesterly winds retain surface waters and the Mackenzie River plume inshore (downwelling conditions), whereas easterlies push them seaward (upwelling conditions) (Macdonald and Yu, 2006). The recent wind-driven acceleration of the Beaufort Gyre (strengthening of the Beaufort Sea High) has promoted the upwelling regime. Accordingly, a progressive switch from eastward to northwestward routing of surface waters has been observed since 2002 (Fichot et al., 2013).

Primary production (PP) in the Beaufort Sea is usually known as being low when compared with other Arctic shelves, with an annual range from 30 to $70 \mathrm{~g} \mathrm{C} \mathrm{m}^{-2} \mathrm{yr}^{-1}$ (Sakshaug, 2004; Carmack et al., 2004). With the ongoing transformation of the atmosphere-ice regime in the Beaufort Sea, the vertical transport of nutrient-rich intermediate waters to the surface through wind-driven upwelling appears to be able to increase PP on the shelf (Tremblay et al., 2011) and at its periphery (Forest et al., 2011). The strength of the spring bloom is closely related to the renewal of nitrate in the upper water column during winter (Tremblay et al., 2008). Then, a subsurface chlorophyll maximum (SCM) rapidly develops and progressively lowers the nitracline over summer (Martin et al., 2010). While large-sized diatom cells dominate the spring bloom, the SCM harbors a more diverse phytoplankton community, numerically dominated by small flagellates. Planktonic and benthic food webs in the Mackenzie Shelf region are fueled by both allochthonous and autochthonous carbon sources (Parsons et al., 1989; Morata et al., 2008; Connelly et al., 2012). But the exact contribution of riverine material to overall ecosystem metabolism remains difficult to quantify, especially as stable isotopes and elemental ratios might provide a distorted view on food web linkages in the Beaufort Sea - i.e., biased toward terrigenous inputs while PP is the primary organic carbon source (Sallon et al., 2011; Pineault et al., 2013). Nevertheless, it is impossible to dismiss the large organic matter flux from the 

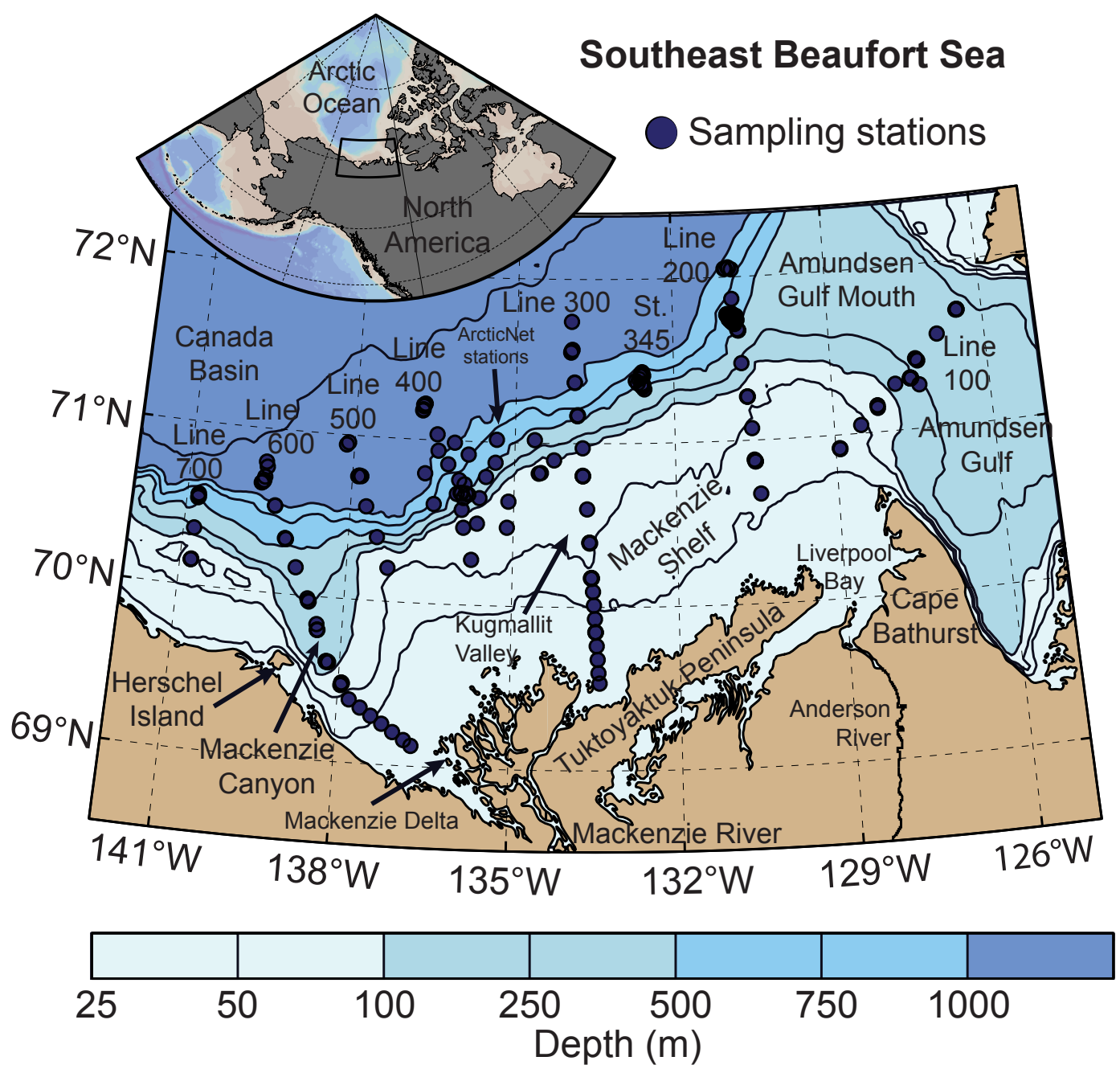

Figure 1. Map of the Mackenzie Shelf region (Beaufort Sea, Arctic Ocean) with position of sampling stations visited in July-August 2009 as part of the ArcticNet-Malina campaign. The ArcticNet sampling stations were located within the exploration license area EL446, whereas transects 100-700 and station 345 correspond to the Malina sampling grid. On each Malina transect, station numbers are listed in descending order from south to north (e.g., stations 170 to 110 from south to north on line 100). In this study, we used the following geographical limits when discussing the spatial variability: (i) the boundary between the shelf and the slope/basin is delineated by the $100 \mathrm{~m}$ isobath; and (ii) the western, central and eastern regions correspond to the areas delimited by $136-141^{\circ} \mathrm{W}, 131-136^{\circ} \mathrm{W}$ and $126-131^{\circ} \mathrm{W}$, respectively.

Mackenzie River. Previous studies comparing heterotrophic carbon demand versus local PP in the region typically proposed that riverine organic carbon input is the major factor explaining the imbalance between the two (e.g., Garneau et al., 2008; Ortega-Retuerta et al., 2012). While this might be appropriate for microbial communities, metazooplankton activity (dominated by copepods) is rather linked to pulses in fresh food supply during spring-summer (e.g., Forest et al., 2011, 2012). Similarly, carbon turnover by benthic organisms is largely related to the distribution of phyto-detritus in surface sediments (Renaud et al., 2007).

Here we used data from the ArcticNet and Malina oceanographic expeditions that successively investigated the southeastern Beaufort Sea in July-August 2009 from the Canadian research icebreaker CCGS Amundsen. The ArcticNet sampling stations were located within a small, enclosed area at the shelf break; whereas the Malina sampling grid was primarily composed of 7 shelf-basin transects (Fig. 1). Two of the Malina transects extended to very shallow waters $(\sim 3 \mathrm{~m}$ depth) where sampling was conducted using a zodiac or a barge (see Doxaran et al., 2012). The ensemble of sampling stations conducted in July-August 2009 constitutes one of the most comprehensive spatial coverage of the Mackenzie Shelf region, within which a wide range of hydrographic, cryospheric and biogeochemical conditions were thoroughly sampled over a $\sim 1$-month period. 


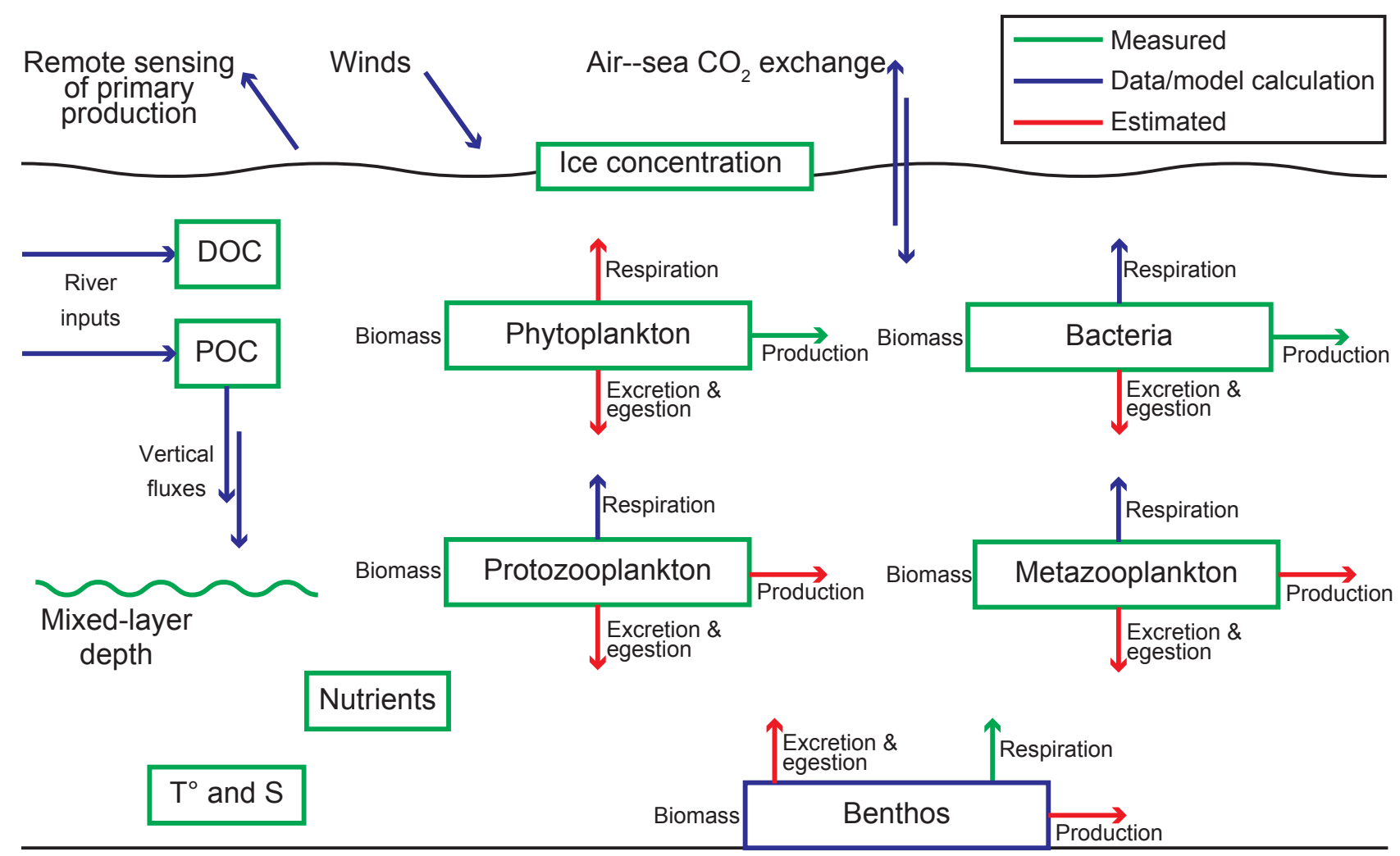

Figure 2. Diagram showing which variables have been directly measured on the field during ArcticNet-Malina, versus which ones have been calculated using a combination of in situ data and statistical models, or rather estimated using knowledge from the literature or deduced from previous regional studies. This schematic aims at facilitating the reading of the methodological Sects. 2.2-2.6. The biophysical context at a regional scale prior and during the field campaign was documented using sea ice, wind and ocean color PP estimates gathered from different sources. For a detailed description of equations linking metabolic pathways of the planktonic and benthic compartments, please see Appendix B in Forest et al. (2011).

This study represents an effort to synthesize a wide range of observations made during the ArcticNet-Malina campaign in the context of previous work in the region and comprises diverse data sets acquired through distinct approaches. Hence, to facilitate the reading of the following methodological sections, we provide a diagram (Fig. 2) showing which variables have been directly measured in the field, versus which ones have been calculated using a combination of in situ data and empirical/statistical models, or rather estimated using knowledge from the literature or deduced from previous regional studies. Standard equations linking metabolic pathways of planktonic and benthic compartments were used (Forest et al., 2011). These equations bind ingestion $(I)$ to respiration $\left(R_{\mathrm{e}}\right)$, egestion/excretion $(e)$, secondary production $\left(P_{\mathrm{S}}\right)$, assimilation efficiency $(\mathrm{AE})$, gross growth efficiency (GGE, for metazoans), or bacterial growth efficiency
(BGE, for bacteria).

$$
\begin{aligned}
I & =P_{\mathrm{s}}+R_{\mathrm{e}}+e \\
\mathrm{GGE} & =P_{\mathrm{s}} / I \\
\mathrm{AE} & =\left(P_{\mathrm{s}}+R_{\mathrm{e}}\right) / I \\
R_{\mathrm{e}} & =I \cdot(\mathrm{AE}-\mathrm{GGE}) \\
e & =I \cdot(1-\mathrm{AE}) \\
\mathrm{BGE} & =P_{\mathrm{s}} /\left(P_{\mathrm{S}}+R_{\mathrm{e}}\right)
\end{aligned}
$$

\subsection{Sea ice conditions, wind reanalysis and ocean color remote sensing}

Daily averaged sea ice concentrations (\% of cover) were obtained from the Ifremer-CERSAT team (http://cersat.ifremer. $\mathrm{fr} /$ ) as initially acquired from the Special Sensor Microwave Imager (SSM/I) located onboard the orbiting sensor of the Defense Meteorological Satellite Program (DMSP). The CERSAT team processes ice maps at $12.5 \mathrm{~km}$ resolution using the daily brightness temperature maps from the National Snow and Ice Data Center (NSIDC; Maslanik and Stroeve, 1999) combined with the Artist Sea Ice algorithm of 
Kaleschke et al. (2001). Sea ice concentrations for the study area were averaged over two 35 -day periods (14 June-19 July and 20 July-24 August) to produce gridded composites of sea ice conditions in summer 2009.

Daily mean wind velocity and direction (meridional and zonal wind at $10 \mathrm{~m}$ ) were obtained from the National Centers for Environmental Prediction (NCEP) North American Regional Reanalysis (NARR) (http://www.esrl.noaa.gov/psd/ data/gridded/data.narr.html). The NARR data are obtained from the high-resolution NCEP Eta Model $(32 \mathrm{~km}, 45$ layers) together with the Regional Data Assimilation System (RDAS) and converted to a Northern Lambert Conformal Conic grid. Wind composites for the same periods as sea ice averages were computed.

Ocean color images from the Moderate Resolution Imaging Spectroradiometer (MODIS-Aqua; Level-3 daily Rrs at 412, 443, 488, 531, 555 and $667 \mathrm{~nm}$ ) were downloaded from the NASA Goddard Earth Sciences Data and Information Services Center (http://oceancolor.gsfc.nasa.gov). For each image, PP rates were calculated using the processing chain and the photosynthesis-irradiance model of Bélanger et al. (2013). This procedure makes use of the state-of-the-art development in ocean color remote sensing and combines sea ice and cloud properties in order to model the incident spectral solar irradiance below the sea surface. It also accounts for absorption by colored dissolved organic matter (CDOM) and non-algal particles, which are known to increase artificially the ratio of chlorophyll (chl) $a$ concentration to the diffuse attenuation coefficient of photosynthetically usable radiation. As this problem still remains a major issue in the coastal Arctic Ocean where river inputs are important (Ben Mustapha et al., 2012), we set a maximum chl $a$ threshold of $30 \mathrm{mg} \mathrm{m}^{-3}$ (Ardyna et al., 2013). The final products were daily maps of PP (4.64 km resolution) that we averaged for the same periods as sea ice and wind conditions.

\subsection{Ocean properties, mixed layer depth and sea-to-air $\mathrm{CO}_{2}$ fluxes}

A conductivity-temperature-depth system (CTD, Seabird SBE-911+) was deployed at every sampling station across the study area (Fig. 1). CTD data were calibrated and verified following the UNESCO Technical Papers (Crease, 1988). Water samples, collected with a rosette system equipped with $22 \times 12$ L Niskin bottles, were taken for salinity calibration using a Guildline Autosal salinometer. All verified CTD data were averaged over $1 \mathrm{~m}$ bins.

The mixed layer depth (MLD) was calculated using the method proposed by Holte and Talley (2009), but modified for the Arctic waters by using only the density profiles. In brief, this algorithm first calculates four possible MLD values with different methods (i.e., threshold value method at $0.05 \mathrm{~kg} \mathrm{~m}^{-3}$, maximum density gradient, intersection between straight line on the mixed layer of density and fitted line on pycnocline, and gradient method) and then analyzes the groupings and patterns within the possible MLDs to select a final MLD estimate (see Holte and Talley, 2009 for a detailed description of each step of the MLD calculation).

Water samples for the determination of total alkalinity $\left(A_{\mathrm{T}}\right)$ and $\mathrm{pH}$ were collected at sea following the protocol of Mucci et al. (2010). $A_{\mathrm{T}}$ and $\mathrm{pH}$ were measured onboard within $4 \mathrm{~h}$ of sample collection. $A_{\mathrm{T}}$ was measured using an automated Radiometer potentiometric titrator and a Red Rod combination $\mathrm{pH}$ electrode. The $\mathrm{pH}$ of samples with salinity $>20$ was determined colorimetrically using a UV visible diode array spectrophotometer and a $5 \mathrm{~cm}$ quartz cell. Phenol red and $m$-cresol purple were used as indicators. The $\mathrm{pH}$ of brackish water samples (salinity $<20$ ) was measured with a potentiometric electrode setup. In situ seawater $\mathrm{CO}_{2}$ fugacity $\left(f \mathrm{CO}_{2} \mathrm{SW}\right)$ and total inorganic carbon (TIC) concentration were calculated from $A_{\mathrm{T}}$ and $\mathrm{pH}$ measurements with the freeware CO2SYS (Lewis and Wallace, 1998) and the carbonate dissociation constants of Mehrbach et al. (1973) as refit by Dickson and Millero (1987). In addition to bottle sampling, a continuous sampling of $p \mathrm{CO}_{2} \mathrm{SW}$ was conducted using an underway system (General Oceanics model 8050; Pierrot et al., 2009) delivering water from a nominal depth of $\sim 5 \mathrm{~m}$ and equipped with a flow-through CTD (Idronaut Ocean Seven 315) as described in Else et al. (2013a). $\mathrm{CO}_{2}$ data from the underway system were corrected for thermodynamic effects and were discarded when the flow to the equilibrator was below $2 \mathrm{~L}$ per min. Validated $p \mathrm{CO}_{2} \mathrm{SW}$ data from the underway system were merged with the bottle data set in a unique database to provide a comprehensive overview of sea surface $\mathrm{CO}_{2}$ concentrations across the study area. Conversion of $f \mathrm{CO}_{2}$ to $p \mathrm{CO}_{2}$ and vice-versa was made using the virial equation of Weiss (1974).

Sea-to-air $\mathrm{CO}_{2}$ fluxes were calculated using the bulk formulation, linearly scaled to sea ice concentration (e.g., Bates et al., 2006; Mucci et al., 2010; Else et al., 2012):

$$
F \mathrm{CO}_{2}=k \alpha\left(p \mathrm{CO}_{2} \mathrm{SW}-p \mathrm{CO}_{2} \mathrm{ATM}\right)(100-\mathrm{SIC} / 100),
$$

where $\mathrm{FCO}_{2}$ is the flux of $\mathrm{CO}_{2}\left(\mathrm{mmol} \mathrm{m}^{-2} \mathrm{~d}^{-1}\right.$, negative values indicate a sink into the ocean while positive values indicate a source for the atmosphere), $k$ is the gas transfer velocity, $\alpha$ is the solubility of $\mathrm{CO}_{2}$ in seawater, $p \mathrm{CO}_{2}$ is the partial pressure of $\mathrm{CO}_{2}$ in the atmosphere (ATM) and surface seawater (SW), and SIC is the sea ice concentration from 0 to $100 \%, p \mathrm{CO}_{2} \mathrm{ATM}$ over the study area was calculated using atmospheric $\mathrm{CO}_{2}$ mixing ratio from the Scripps Facility located in Point Barrow (Keeling et al., 2001; http://scrippsco2.ucsd.edu), according to the equations of Weiss (1974) and Weiss and Price (1980) that make use of in situ sea surface temperature (SST), sea surface salinity, and barometric pressure (from the ship meteorological tower). To keep coherency with previous studies in the region (Mucci et al., 2010; Else et al., 2012), we adopted the Sweeney et al. (2007) parameterization for $k$

$k=0.27 U^{2}(S c / 660)^{(-1 / 2)}$ 
where $U$ is the wind speed at $10 \mathrm{~m}$, and $S c$ is the Schmidt number. For a discussion on the uncertainty about the parameterization of $k$ and resulting $\mathrm{CO}_{2}$ fluxes, see Appendix A. The sea surface temperature (SST) (required for Sc) was available from both our underway system and from the CTDrosette. Wind speed was measured at $14.5 \mathrm{~m}$ above sea level using a wind monitor (RM Young model 05106) housed on a meteorological tower located on the ship's foredeck. Wind speed was scaled to $10 \mathrm{~m}$ assuming the log-linear wind speed relationship to height. Wind data with direction exceeding $\pm 100^{\circ}$ from the ship's bow were removed from the analysis (Mucci et al., 2010).

\subsection{Riverine inputs, organic carbon pools and vertical particle fluxes}

Daily water discharge and particulate matter load from the Mackenzie River (station Arctic Red River 10LC014, $67^{\circ} 27^{\prime} 21^{\prime \prime} \mathrm{N}, 133^{\circ} 45^{\prime} 11^{\prime \prime} \mathrm{W}$ ) and Anderson River (station Carnwath River $10 \mathrm{NC} 001,68^{\circ} 37^{\prime} 50^{\prime \prime} \mathrm{N}, 128^{\circ} 25^{\prime} 17^{\prime \prime} \mathrm{W}$ ) were obtained from the Water Survey of Canada (http://www. wsc.ec.gc.ca). It should be noted, however, that the Anderson River contributes to less than $0.01 \%$ of the total river runoff in the Beaufort Sea when compared against the Mackenzie River. Water discharge data collected at Arctic Red River represent roughly $94 \%$ of the total Mackenzie catchment, as they correspond to the most downstream station before the Mackenzie River splits into many channels in the estuary (Leitch et al., 2007). For the purpose of our study, the actual delivery of sediment beyond the Mackenzie estuary was estimated at $50 \%$ of the load at Arctic Red River, which was further segmented into $83 \%$ in the western side of the delta and $17 \%$ in the Kugmallit Bay east of the delta (O'Brien et al., 2006). The output from the Anderson River in Liverpool Bay (Fig. 1) was assumed to be $50 \%$ of what is measured at Carnwath River. The mean percentage of POC in riverine particulate load at both rivers was assumed to be $2 \%$ (Doxaran et al., 2012). The concentration of DOC at the Mackenzie and Anderson River mouths was estimated using the linear equation of Matsuoka et al. (2012) (DOC $=486-$ $16 \times$ salinity; $r^{2}=0.89 ; p<0.0001$ ) and a salinity of zero.

Concentrations of POC in the water column were determined using two methodologies. The first one involved the filtration of known volumes of seawater in triplicates through pre-weighed and pre-combusted $25 \mathrm{~mm} \mathrm{GF} / \mathrm{F}$ Whatman filters $(0.7 \mu \mathrm{m}$ pore size $)$. These samples were stored at $-80^{\circ} \mathrm{C}$ on the ship before further acidification (to remove the inorganic carbon fraction) followed by a classical CHN analysis (Perkin Elmer 2400 , combustion at $925^{\circ} \mathrm{C}$ ) on land (as described in Doxaran et al., 2012). The second method used a similar filtration procedure, but the determination of POC was carried using the wet-oxidation technique of Raimbault et al. (1999a). In total, 130 samples were processed with the $\mathrm{CHN}$ and 248 samples were analyzed with the wet-oxidation method. The two data sets were subsequently compared for coherency and combined into one single database.

Samples for the determination of total organic carbon were collected into $50 \mathrm{~mL}$ glass Schott bottles, immediately acidified with $\mathrm{H}_{2} \mathrm{SO}_{4}$ and stored for further analysis. Prior to oxidation, samples were bubbled with a high-purity oxygen/nitrogen gas stream for $15 \mathrm{~min}$. Persulfate wet-oxidation was used to digest the organic matter in these unfiltered samples (Raimbault et al. (1999b). The concentration of DOC was calculated from the total organic fraction by subtracting POC values obtained from the corresponding GF/F fraction. Reference water from the Sargasso Sea was used to verify the accuracy of DOC measurements (Hansell Laboratory, Bermuda Biological Station for Research). All reagents and blanks were prepared using fresh Millipore Milli-Q plus water.

Vertical POC fluxes during ArcticNet-Malina 2009 were determined using a combination of sediment trap measurements and camera recordings (Forest et al., 2013). Briefly, particles in the range $0.08-4.2 \mathrm{~mm}$ (in equivalent spherical diameter, ESD) recorded with an Underwater Vision Profiler 5 (UVP5, Picheral et al., 2010) were transformed into vertical POC fluxes with a regional empirical algorithm linking sediment trap fluxes and the UVP5 data set. The algorithm was developed using an optimization procedure following Guidi et al. (2008) and provided a good agreement between sediment trap POC fluxes and UVP5 fluxes $\left(r^{2}=0.68, n=21\right)$. This methodology allowed us to obtain vertical POC fluxes at high vertical resolution at 154 stations.

\subsection{Nutrients, gross primary production and phytoplankton dynamics}

Nutrient samples were collected at standard depths in the water column (Tremblay et al., 2008; Martin et al., 2010). Samples for the determination of nitrate $\left[\mathrm{NO}_{3}^{-}\right]$and nitrite $\left[\mathrm{NO}_{2}^{-}\right]$were dispensed into polyethylene flasks and poisoned with mercuric chloride (Kirkwood, 1992) for later analysis. Nitrate and nitrite were measured using a Technicon AutoAnalyzer II (Tréguer and LeCorre (1975) following Raimbault et al. (1990). Ammonium concentration $\left[\mathrm{NH}_{4}^{+}\right]$ was measured directly on board using the sensitive fluorescent method of Holmes et al. (1999). The reproducibility of nutrient measurements was also assessed $(0.1 \%)$ using in-house standards compared with commercial products (http://www.osil.co.uk/Products/SeawaterStandards).

Rates of carbon fixation, nitrate and ammonium uptake were measured using a dual ${ }^{13} \mathrm{C} /{ }^{15} \mathrm{~N}$ isotopic technique as described by Raimbault and Garcia (2008) (see also OrtegaRetuerta et al., 2012). Briefly, water samples were collected at 6 depths between the surface and the 1-0.3\% light irradiance and poured into acid-cleaned polycarbonate flasks. Labeled ${ }^{13} \mathrm{C}$ sodium bicarbonate $\left(\mathrm{NaH}^{13} \mathrm{CO}_{3}\right)$ and ${ }^{15} \mathrm{~N}$-tracers $\left(\mathrm{K}^{15} \mathrm{NO}_{3}\right.$ or $\left.{ }^{15} \mathrm{NH}_{4} \mathrm{Cl}\right)$ were added to each bottle to obtain $\approx 10 \%$ final enrichment. Incubations were carried out 
immediately following tracer addition. On-deck incubators consisted of 6-8 opaque boxes allowing 50, 25, 15, 8, 4, 1 and $0.3 \%$ light penetration. Incubators were maintained at sea-surface temperature $\left(\sim 0{ }^{\circ} \mathrm{C}\right)$ with ice packs for $24 \mathrm{~h}$. Incubations were terminated by filtration through precombusted $\left(450^{\circ} \mathrm{C}\right)$ Whatman $\mathrm{GF} / \mathrm{F}$ filters $(25 \mathrm{~mm}$ diameter, $0.7 \mu \mathrm{m}$ pore) using a low vacuum pressure to measure the final ${ }^{15} \mathrm{~N} /{ }^{13} \mathrm{C}$ enrichment ratio in the particulate organic matter and the concentrations of particulate carbon and particulate nitrogen. The $f$ ratios were calculated as the ratio of nitrate uptake to the sum of nitrate and ammonium uptake as measured on particles retained on filters (Tremblay et al., 2006). The dual isotopic enrichment analysis was performed on an Integra-CN mass spectrometer. Net, daily fixation rates of ${ }^{13} \mathrm{C}$ into particulate organic matter were calculated from the mean of 2 replicates according to Collos and Slawyk (1984), with a time 0 enrichment of $1.085 \% \pm 0.009 \%(n=$ $15)$. We estimated gross PP by (1) summing the net particulate rates of carbon fixation 9Raibmault and Garcia, 2008); (2) using estimates of respiration and DOC production, assuming that these components represent 10 and $15 \%$ of gross $\mathrm{PP}$, respectively (as identified as suitable percentages for the Beaufort Sea ecosystem by Forest et al., 2011).

Phytoplankton biomass estimates were based on 88 samples acquired at 20 stations across the study area. Samples for microscopic analysis were preserved in acidic Lugol's solution and stored in the dark at $4{ }^{\circ} \mathrm{C}$ until analysis. Counting was performed following the Utermöhl method (Lund et al., 1958) using an inverted microscope (Wild \& Zeiss Axiovert 10). Phytoplankton abundance obtained by taxonomy (cells $>3 \mu \mathrm{m}$ ) and cytometry (picoeukaryotes 1-3 $\mu \mathrm{m}$ ) were converted into carbon biomass by multiplying the mean cellular carbon content by abundance (Menden-Deuer and Lessard, 2000) by abundance.

\subsection{Biomass, respiration and production of bacteria, zooplankton and benthos}

Bacterial biomass and bacterial production (BP) during Malina 2009 were obtained from Ortega-Retuerta et al. (2012) (see also Forest et al., 2013). Bacterial abundance was estimated at sea using a FACS ARIA cytometer (Becton Dickinson, San Jose, USA) after DNA staining with SYBR Green. Abundance was converted to biomass using a cell-to-carbon conversion factor of $15.2 \mathrm{fg} \mathrm{C}^{-1 l^{-1}}$ as based on a mean estimated cellular biovolume of $0.040 \pm 0.009 \mu \mathrm{m}^{3}$ and the fac-

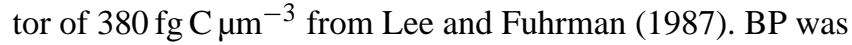
measured using the ${ }^{3} \mathrm{H}$-leucine incorporation method (Kirchman, 1993) as modified by Smith and Azam (1992). Leucine incorporation rates were converted into carbon production using the conversion factor of $1.2 \mathrm{~kg} \mathrm{C}$ produced per mole of leucine (Forest et al., 2011, 2013). Bacterial respiration (BR) was calculated using the inverse of Eq. (6) as follows:

$\mathrm{BR}=(\mathrm{BP} / \mathrm{BGE})-\mathrm{BP}$, where BGE is the bacterial growth efficiency. Here, we implemented BGEs as variable parameters (from 0.5 to 25 ) depending on the stratum (surface or subsurface) within which BR was estimated. Varying BGEs in the surface layer were calculated using a linear relationship found between the surface BGEs estimated from field measurements by Ortega-Retuerta et al. (2012) and the water column standing stocks of chl $a\left(\mathrm{mg} \mathrm{chl} a \mathrm{~m}^{-2}\right)$ assessed by Forest et al. (2013) during Malina. The relationship provided the following equation: $\mathrm{BGE}=0.952(\mathrm{chl} a)+2.21\left(r^{2}=0.99, n=\right.$ $5)$. Since there was only one subsurface BGE value available in Ortega-Retuerta et al. (2012), the subsurface BGEs were rather calculated using the linear relationship of Nguyen et al. (2012) linking BP and BGE in the southern Beaufort Sea.

The abundance of protozooplankton was measured using taxonomic work (Utermöhl method) on Lugol-preserved samples and the carbon biomass was estimated following Menden-Deuer and Lessard (2000). We further estimated protozooplankton respiration according to the log-log equation of Caron et al. (1990) linking the biovolume of protozoans to weight-specific respiration rates. Since this equation provides respiration rates normalized to $20^{\circ} \mathrm{C}$, protozoan respiration estimates were corrected for in situ temperature using a $Q_{10}$ of 2 (Fenchel, 2005). Biovolume conversion factors for the different protist species were compiled from Olenina et al. (2006) or estimated based on cell shape and dimensions (Bérard-Therriault et al., 1999) using appropriate geometric formulas (Olenina et al., 2006).

The carbon biomass of mesozooplankton was obtained from Forest et al. $(2012,2013)$ who documented the mesozooplankton community structure in summer 2009 across the Mackenzie Shelf with a combination of zooplankton net tows $\left(1 \mathrm{~m}^{2}, 200 \mu \mathrm{m}\right.$ mesh size) and underwater images obtained with the UVP5 (validated manually). The proportion of mesozooplankton versus small zooplankton (including copepod nauplii) collected with a $50 \mu \mathrm{m}$ mesh size (Robert et al., 2011) at the ArcticNet stations (Fig. 1) was used to correct the whole metazooplankton biomass with the aim of providing biomass estimates for the broadest size spectrum as possible. We then divided the whole metazooplankton biomass into two size categories $(<1 \mathrm{~mm}$ and $>1 \mathrm{~mm})$ as based on their apparent ESD. The biomass in the $>1 \mathrm{~mm}$ size-class was dominated by large calanoid copepods, while cyclopoids and small calanoids dominated in the $<1 \mathrm{~mm}$ size-class (see Forest et al., 2012 for further details). Biomass of metazooplankton was converted into respiration outflows using the conversion factors of Darnis and Fortier (2012) who measured specific respiratory carbon rates per unit of dry weight (DW) biomass on bulk size-fractions $(<1 \mathrm{~mm}$ and $>1 \mathrm{~mm}$ ) of zooplankton over a quasi-annual cycle in the Beaufort Sea in 2007-2008. For our study spanning late July to mid-August, we used a conversion factor of $10 \mu \mathrm{g} \mathrm{C} \mathrm{mg} \mathrm{DW}^{-1} \mathrm{~d}^{-1}$ for the large zooplankton fraction and a factor of $15 \mu \mathrm{g} \mathrm{C} \mathrm{mg} \mathrm{DW}{ }^{-1} \mathrm{~d}^{-1}$ for the small fraction. 
The inverse modeling estimates of zooplankton gross growth efficiency and assimilation efficiency of Forest et al. (2011) (see their Table 7) were used to calculate the secondary production of protozoans and metazooplankton on the basis of carbon respiration outflows.

Respiration fluxes from the benthos were based on the benthic oxygen fluxes measured in triplicates at 8 stations across the study area (see Table 2 in Link et al., 2013) and a molar ratio of oxygen to carbon of 1.25 (Langdon, 1988). It is known that oxygen fluxes are not perfect proxies for carbon turnover rates (Link et al., 2013), but they provide at least minimal estimates that can be used to obtain a rough picture of benthic activity. Benthic carbon demand was calculated assuming a net growth efficiency of 0.3 and an assimilation efficiency of 0.8 (Brey, 2001). The relationship of Renaud et al. (2007) linking benthic carbon demand to epifaunal biomass in the Beaufort Sea $\left(r^{2}=0.86, p<0.001\right.$, $n=11$ ) was used to provide a coarse estimation of benthic biomass.

\subsection{Data analyses, mapping and net community production estimates}

The various data sets collected during ArcticNet-Malina were analyzed to explore spatial variability and large-scale differences in physical, biogeochemical and ecological functioning. Sub-regions and sub-layers were defined as follows. The mixed-layer depth was used to delimit the boundary between the surface and subsurface layer, while the subsurface layer extended down to $100 \mathrm{~m}$ depth maximum. The threshold between the on-shelf and off-shelf region was set at the $100 \mathrm{~m}$ isobath. The northward bound of the off-shelf zones was set to the $2000 \mathrm{~m}$ isobath. The western, central and eastern regions used for averaging diverse values corresponded to the areas delimited by $136-141^{\circ} \mathrm{W}, 131-136^{\circ} \mathrm{W}$ and $126-131^{\circ} \mathrm{W}$, respectively. The whole study region was defined as the area confined within $126-141^{\circ} \mathrm{W}$ and within the $2-2000 \mathrm{~m}$ isobaths. It corresponds to a parallelogram of ca. $254.5 \mathrm{~km}$ width $\times 550.5 \mathrm{~km}$ length $\left(\sim 140.1 \times 10^{3} \mathrm{~km}^{2}\right)$.

All observational data maps presented in this study were computed using the Gridfit function developed for Matlab (MathWorks, USA) by D'Errico (2006). Gridfit is a powerful modeling tool that produces a surface representing the behavior of supplied data as closely as possible. It handily allows for replicates, regular and scattered data, noise and extreme values - as it builds a mesh-grid directly from the data instead of interpolating a linear estimate to a 2D surface. As such, it is more convenient than Kriging and standard interpolation methods (e.g., nearest neighbor, linear) when working with irregular oceanographic data. Gridfit is also able to smoothly extrapolate beyond the convex envelope of the supplied data set in a more clever way than polynomial models. It is fully flexible and uses a differential equation solver to compute a set of nodes forming a rectangular lattice that contains the data points. For further details on the methodological and philosophical underpinnings of Gridfit, see D'Errico (2006).

Net community production (NCP) estimates were calculated using the following equation:

$\mathrm{NCP}=\mathrm{GPP}-\mathrm{CR}$,

where GPP is the total gross primary production as estimated from in situ PP measurements (i.e., not from remote sensing), and CR is the total community respiration calculated as the sum of all respiration fluxes from phytoplankton, bacteria, protozooplankton, as well as small and large metazooplankton. Respiration fluxes from the benthos over the shelf $(<100 \mathrm{~m}$ isobath) were included in the NCP estimates of the subsurface layer that extended from the MLD down to $100 \mathrm{~m}$ maximum. For a discussion on the uncertainty related to the NCP estimates, see Appendix A.

Linear regressions of NCP against GPP were conducted with the aim of estimating threshold GPP, i.e., the GPP value at which NCP becomes positive (Duarte and Regaudie-deGioux, 2009). Here, threshold GPPs were used as further indicators of the spatial variability of heterotrophy vs. autotrophy across the Mackenzie Shelf. Given that GPP and $\mathrm{NCP}$ are both dependent variables, regressions were computed using a model II least squares bisector equation (Geometric Mean Functional Relationship; Sprent and Dolby, 1980). These linear models determine the slope of the line (through the centroid) that bisects the minor angle between the regressions of Y-on-X and X-on-Y. The Matlab function lsqbisec (Peltzer, 2008) was used to compute the model II least squares bisector regressions.

\section{Results}

In addition of the results presented here, we refer the reader to the supplementary material available online. This supplementary material presents a detailed summary of all key results from the gridded maps produced in the framework of our synthesis study.

\subsection{Overview of sea ice, wind and satellite-derived primary productivity}

Sea ice and wind conditions in summer 2009 in the Beaufort Sea were influenced by a shift in the atmospheric pattern that occurred between July and August. Over the early summer, the region was affected by a high-pressure system (anticyclone) located around $70^{\circ} \mathrm{N} 156^{\circ} \mathrm{W}$ that brought clear-sky conditions, southward advection of old sea ice from the Arctic pack (Fig. 3a), and persistent northerly winds (Fig. 3c). In early August, the atmospheric conditions that were observed in the months of June and July collapsed and the mid-to-late summer season was characterized by a low-pressure system that caused cloudy conditions. This cyclone had a catalytic effect on the melt of sea ice through the dispersal of ice floes, 
which resulted in what can be seen in Fig. $3 b-$ i.e., large areas of open water over the Mackenzie Shelf and a maximum ice concentration of $\sim 80 \%$ over the deep basin. The mean wind pattern observed over the field campaign (Fig. 3d) was computed as a weak easterly wind $\left(<5 \mathrm{~km} \mathrm{~h}^{-1}\right)$, which was a result of the disruption of the anticyclone.

Remote sensing estimates of PP (Fig. 3d and e) showed that PP appeared to be primarily intertwined with the Mackenzie River plume that propagated westward along the Alaskan coast under the influence of northerly winds in June-July. Hence, given the easterly wind pattern that was calculated for late July-August, turbid waters from the Mackenzie River had, presumably, no impact at all on PP estimates east of Kugmallit Valley or Canyon in summer 2009.

\subsection{Sea surface physics, inorganic carbon and sea-to-air $\mathrm{CO}_{2}$ fluxes}

The trajectory of the Mackenzie River plume during JulyAugust was clearly visible on the map of sea surface salinity (Fig. 4a). This confirmed that the eastern portion of the study area was not influenced by any substantial freshwater input. Even surface waters on the eastern shelf remained around a salinity of 30 , which is not a particularly low value for the Beaufort Sea. Surface waters with a salinity $<20$ were restricted to the inner shelf close to the Mackenzie delta. Brackish surface waters were also generally characterized by increased temperature (up to $\sim 10^{\circ} \mathrm{C}$ in very shallow waters, Fig. 4b). Near $-0^{\circ} \mathrm{C}$ surface waters were associated with the presence of sea ice and a transition from $0^{\circ} \mathrm{C}$ to $10^{\circ} \mathrm{C}$ was measured as the distance to the ice edge increased.

The vertical extent of the MLD generally increased as sea surface salinity increased and as temperature decreased (Fig. 4c). There was no clear difference between stations affected by the absence or presence of sea ice. Mapping of MLDs showed that the mouth of the Amundsen Gulf was the zone where the MLD extended the deepest (down to $\sim 17 \mathrm{~m}$ ), but MLD values were small overall, with a mean \pm standard deviation (SD) of $8.1 \pm 3.1 \mathrm{~m}$ for the whole study area. Here, MLDs were used to delimit the surface and subsurface layers.

Gridded concentrations of TIC at the ocean surface showed a clear gradient from west to east (Fig. 4d). TIC concentrations were significantly $(p<0.01)$ related to salinity $(S)$ in the mixed layer $\left(\right.$ TIC $=48.4 \times S+562.6 ; r^{2}=0.88$; $n=77$ ) if we omit data strongly influenced by the Mackenzie River plume (i.e., the inner shelf)

The spatial variability of $\mathrm{CO}_{2}$ fugacity at the sea surface was high (ranging from 198 to $660 \mu \mathrm{atm}$, mean $\pm \mathrm{SD}$ of $322 \pm 60 \mu \mathrm{atm}$ ), with marked maxima on the outer eastern shelf, near the Mackenzie River delta and toward the Alaskan coast, and to some extent in the Amundsen Gulf (Fig. 4e).

The computation of sea-to-air $\mathrm{CO}_{2}$ fluxes revealed that the zones affected by elevated $\mathrm{CO}_{2}$ fugacity were the only regions acting as sources of carbon to the atmosphere (Fig. 4f),
(14 Jun - 19 Jul)
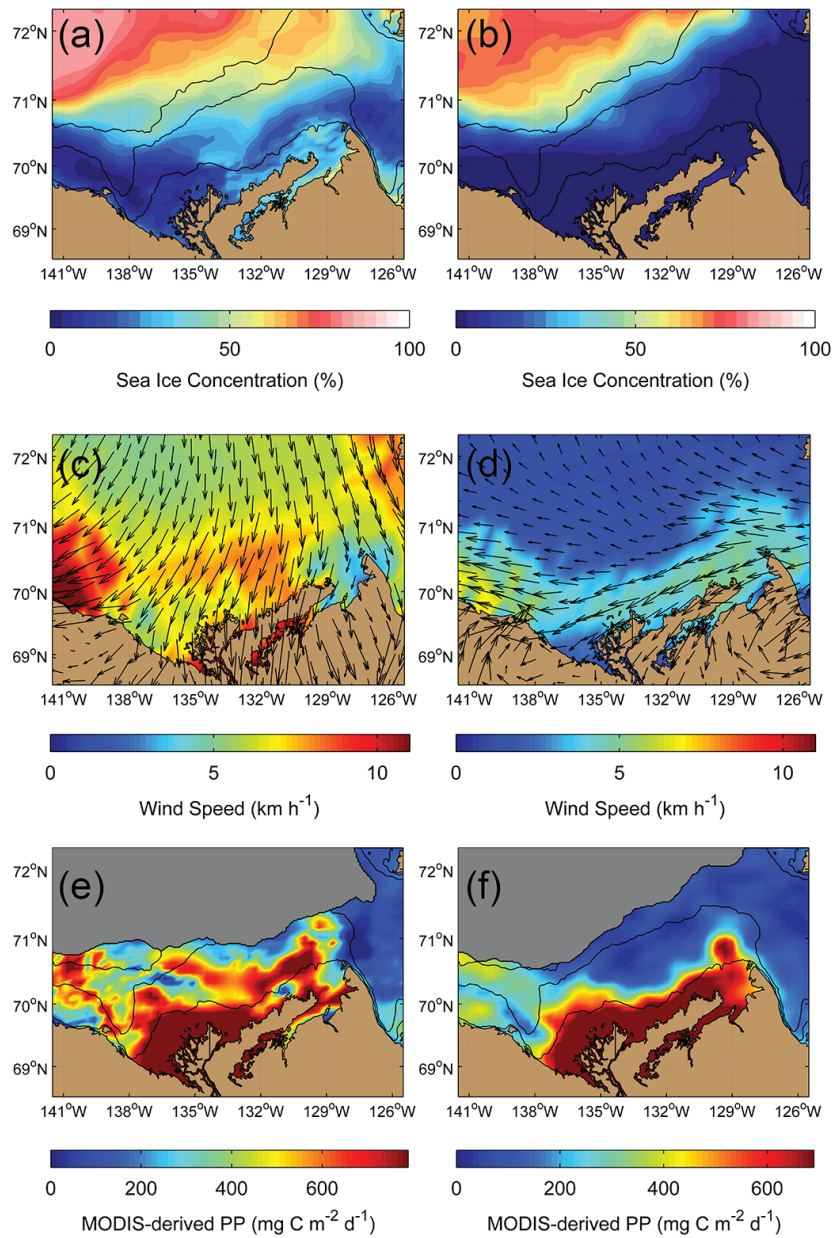

Figure 3. Composites of (a, b) sea ice concentration (\% ice coverage) from the SSM/I-DMSP orbiting sensor, $(\mathbf{c}, \mathbf{d})$ wind velocity and vectors from the NCEP-NARR reanalysis, and (e, f) rates of primary production (PP) derived from the MODIS satellite, as averaged for the 35-day period just before (14 June-19 July, left panels) and just during (20 July-24 August, right panels) the ArcticNetMalina field campaign. The grayscale masks in panels (e, f) depict the areas where no satellite pixels could be extracted from the discrete MODIS images because of the presence of sea ice. Bathymetric contours are 20,100 and $1000 \mathrm{~m}$.

especially the river delta (up to $\sim 20 \mathrm{mmol} \mathrm{C} \mathrm{m}^{-2} \mathrm{~d}^{-1}$ ) and the localized hotspot northwest of Cape Bathurst (up to $\left.\sim 10 \mathrm{mmol} \mathrm{C} \mathrm{m}^{-2} \mathrm{~d}^{-1}\right)$. Other areas were acting as a carbon sink, with maximum drawdown of $\mathrm{CO}_{2}$ on the mid-toouter shelf north of the Mackenzie River delta and near the Banks Island shelf (down to $\sim-10 \mathrm{mmol} \mathrm{C} \mathrm{m}^{-2} \mathrm{~d}^{-1}$ ). Overall, the southeastern Beaufort Sea acted as a weak sink of atmospheric $\mathrm{CO}_{2}$ in July-August 2009 with a mean uptake of $-2.0 \pm 3.3 \mathrm{mmol} \mathrm{C} \mathrm{m}^{-2} \mathrm{~d}^{-1}$. 

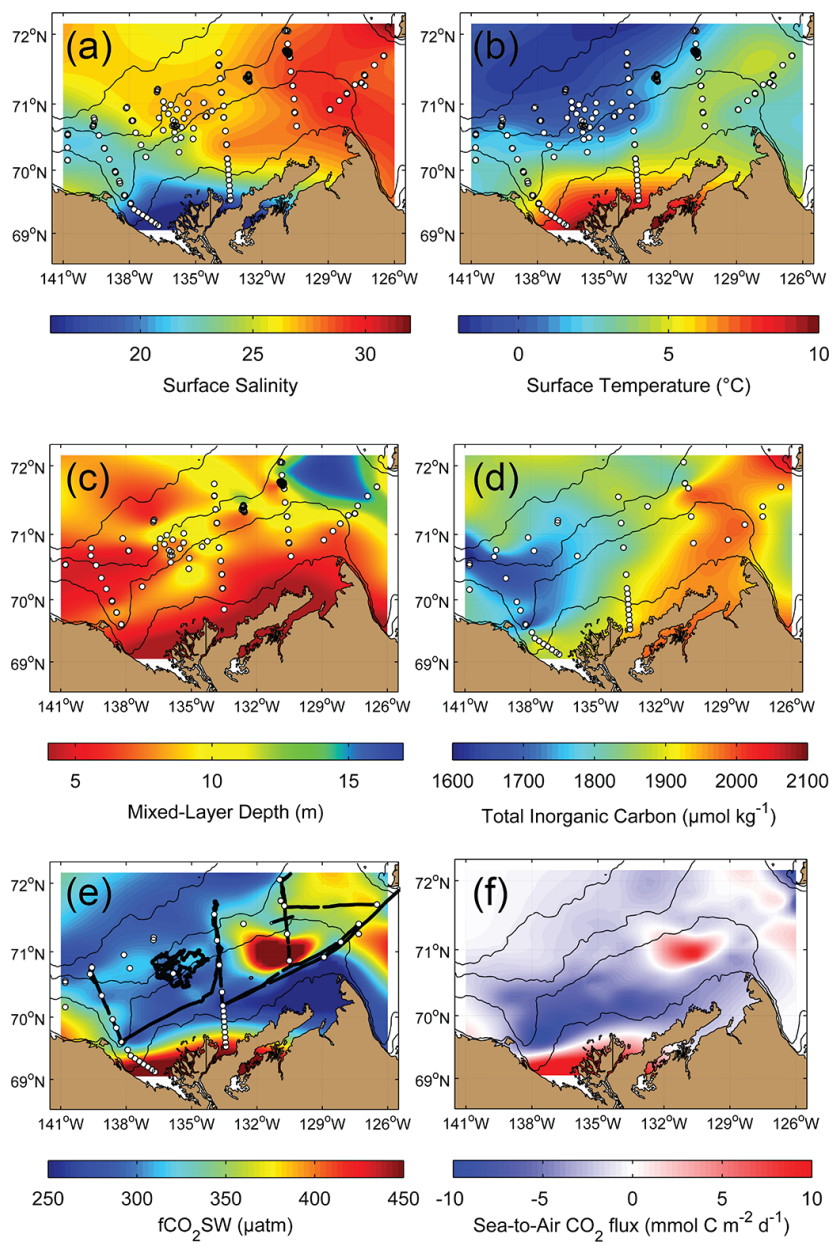

Figure 4. Gridded composites of in situ physico-chemical data obtained at the sampling stations (white dots) conducted in the Beaufort Sea in mid-summer 2009 (Fig. 1): (a) surface salinity, (b) surface temperature, (c) depth of the mixed layer delimiting the surface and subsurface layers as used in this study, (d) concentration of dissolved inorganic carbon, (e) sea surface $\mathrm{CO}_{2}$ fugacity (combined data set from the underway system and bottle data), and (f) the seato-air $\mathrm{CO}_{2}$ fluxes (blue: flux to the ocean; red: to the atmosphere) as computed following the methodology described in Sect. 2.3. Bathymetric contours are 20,100,1000, and $2000 \mathrm{~m}$. The region close to Cape Bathurst on the eastern shelf is known to be a region where wind-driven upwelling is enhanced by the steep topography (see Williams and Carmack, 2008).

\subsection{Bulk budget of organic carbon pools, river inputs and vertical fluxes}

We developed a non-steady-state budget of bulk carbon fluxes and pools for the Mackenzie Shelf in July-August 2009 (Fig. 5) using estimates of organic carbon inputs from the Mackenzie River and Anderson River, POC and DOC measurements in the water column, and vertical POC fluxes. The budget summary is presented as spatial averages across the western, central and eastern zones of the study area as delimited by $136-141^{\circ} \mathrm{W}, 131-136^{\circ} \mathrm{W}$ and $126-131^{\circ} \mathrm{W}$, respectively.

The main result of this bulk budget is the fact that POC inventories were overall higher on the eastern shelf than on the central and western shelf, despite the tremendous POC input from the Mackenzie River, which delivered a daily average load of $3253 \pm 2183 \mathrm{tPOCd}^{-1}$ in these two zones combined. The mean total inventory of POC (integrated vertically, sum of the surface and subsurface layers) in the eastern region (Fig. 5c) was $18.3 \pm 1.5 \mathrm{~g} \mathrm{C} \mathrm{m}^{-2}$, whereas it was $9.6 \pm 1.0 \mathrm{~g} \mathrm{C} \mathrm{m}^{-2}$ in the western zone (Fig. 5a) and $11.7 \pm 1.6 \mathrm{~g} \mathrm{C} \mathrm{m}^{-2}$ in the central region (Fig. 5b). Similarly, the quantity of POC relative to ambient DOC roughly doubled from west to east (from $\sim 6.0 \%$ to $\sim 13.7 \%$; Fig. 5). This suggests that DOC concentrations remain relatively the same across the study area when integrated vertically in the upper $100 \mathrm{~m}$.

A second key result of this summary concerns vertical POC fluxes that did not follow the same pattern as POC inventories. When averaged across the three zones, mean vertical POC fluxes were higher in the central zone $\left(1790 \pm 122 \mathrm{mg} \mathrm{C} \mathrm{m}^{-2} \mathrm{~d}^{-1}\right)$, compared against the eastern $\left(897 \pm 98 \mathrm{mg} \mathrm{C} \mathrm{m}^{-2} \mathrm{~d}^{-1}\right)$ and western $\left(669 \pm 141 \mathrm{mg} \mathrm{C} \mathrm{m}^{-2} \mathrm{~d}^{-1}\right)$ regions. In addition, vertical POC fluxes injected into the benthic boundary layer (as derived from UVP5 recordings) were particularly high on the innermid shelf $\left(<60 \mathrm{~m}\right.$ isobath, $\left.\sim 1200-4100 \mathrm{mg} \mathrm{C} \mathrm{m}^{-2} \mathrm{~d}^{-1}\right)$ when compared to the relatively low POC inventories found in shallow waters $\left(\sim 1600-2900 \mathrm{mg} \mathrm{C} \mathrm{m}^{-2}\right)$, implying that the residence time of POC in the water column near the coast is very low and/or that the area is affected by resuspension. Overall, estimates of vertical POC fluxes over the shelf were one to two orders of magnitude greater than offshore.

\subsection{Nutrient dynamics, phytoplankton biomass and primary production}

During ArcticNet-Malina 2009, nitrate represented 96.6\% of the total nitrogenous nutrient concentrations in the upper $100 \mathrm{~m}$, while nitrite and ammonium accounted for 1.4 and $2.0 \%$, respectively. In surface waters, nitrate concentrations were typically lower than $0.01 \mu \mathrm{M}$, except close to the Mackenzie River delta, where undiluted freshwater with a nitrate of $3.6 \mu \mathrm{M}$ was found. Below the surface mixed layer (Fig. 4c), nitrate remained depleted typically down to 40 $50 \mathrm{~m}$ depth, followed by a clear nitracline associated with the increasing presence of Pacific-derived waters that occupied the 50-200 m layer. A three-dimensional view of nitrate concentrations (as measured at the Malina cross-shelf transects) provided synoptic insights on the geographical and vertical variability of the nitracline during our study (Fig. 6). In this figure, we can observe a clear cross-shelf structure of nitrate-rich waters that propagated inshore within the bottom $10-15 \mathrm{~m}$ of the water column. This oblique expansion (along the isopycnals) of the nitracline from the basin to the shelf 


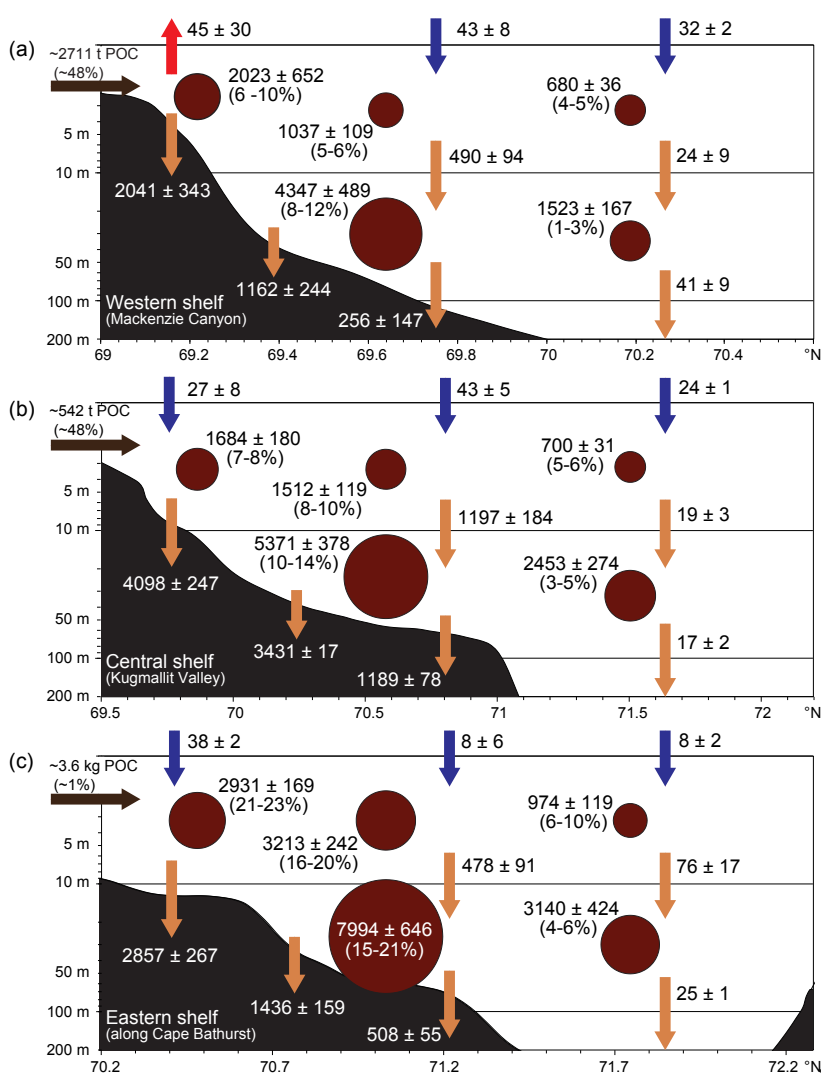

Figure 5. Cross-shelf averages (mean \pm 0.95 confidence interval) of particulate organic carbon (POC) inventories (dark brown circles), vertical POC fluxes (light brown arrows), riverine POC inputs (black arrows), and sea-to-air $\mathrm{CO}_{2}$ fluxes (red and dark blue arrows). All pool units (circles) are in $\mathrm{mg} \mathrm{C} \mathrm{m}^{-2}$ and all flux units (arrows) are in $\mathrm{mg} \mathrm{C} \mathrm{m}^{-2} \mathrm{~d}^{-1}$, except the riverine inputs (which are in tons or $\mathrm{kg}$ per day). The percentage in brackets associated with every POC inventory and river input is the fraction of POC in total organic carbon (particulate + dissolved) that each value represents. The western, central and eastern regions correspond to the areas delimited by $136-141^{\circ} \mathrm{W}, 131-136^{\circ} \mathrm{W}$ and $126-131^{\circ} \mathrm{W}$, respectively (Fig. 1). For a detailed description on how each variable has been estimated, please see Sect. 2.4.

was particularly visible at transects conducted north of Cape Bathurst and in the Mackenzie Canyon. In the head of the canyon, we estimated using Delaunay triangulation that waters just below the surface contained nitrate concentration up to 6-7 $\mu \mathrm{M}$ (Fig. 6).

Relatively high GPP rates $\left(\sim 200-500 \mathrm{mg} \mathrm{C} \mathrm{m}^{-2} \mathrm{~d}^{-1}\right.$; based on on-deck incubations) during our field survey were confined to the surface (above MLD) inshore environment (within the $20 \mathrm{~m}$ isobath) and to some extent to the mid-shelf region close to Cape Bathurst (Fig. 7a). Elsewhere, GPP in surface waters remained at very low levels $\left(\sim 10-50 \mathrm{mg} \mathrm{C} \mathrm{m}^{-2} \mathrm{~d}^{-1}\right)$. Beyond the inner shelf, GPP was actually higher below the surface (below MLD) than within the surface mixed layer, with rates up to

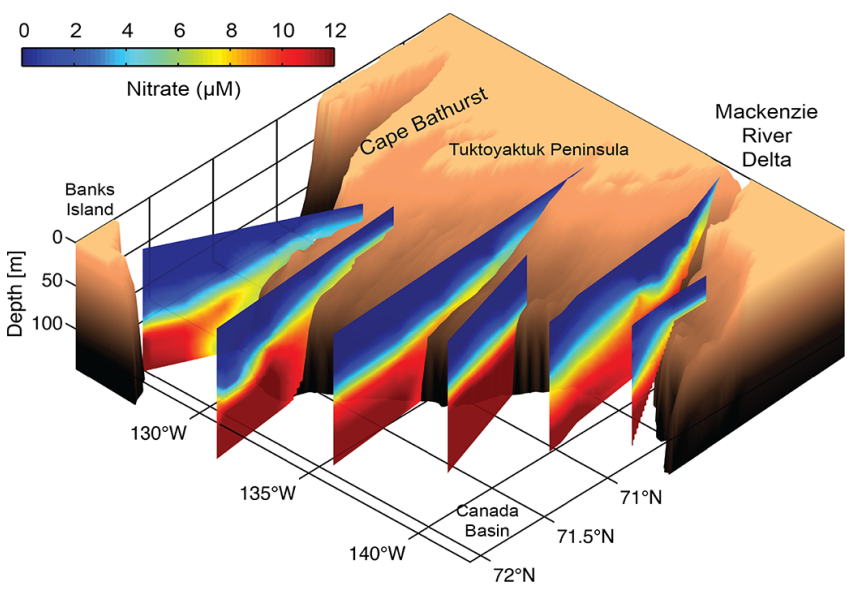

Figure 6. Three-dimensional view of the Mackenzie Shelf region showing the nitrate concentration as measured at transects 100, 200, 300, 400, 600 and 700 (from left to right) during the Malina expedition (Fig. 1). Each vertical slice corresponds to a gridded composite of nitrate concentration measured at standard depths along the cross-shelf sampling line.

$75-90 \mathrm{mg} \mathrm{C} \mathrm{m}^{-2} \mathrm{~d}^{-1}$. When spatially averaged over the whole study area $\left(\sim 140.1 \times 10^{3} \mathrm{~km}^{2}\right)$, GPP in the surface layer was $55.9 \pm 82.7 \mathrm{mg} \mathrm{C} \mathrm{m}^{-2} \mathrm{~d}^{-1}$, which represented on the average $62.6 \%$ of the total GPP in the upper $100 \mathrm{~m}\left(89.2 \pm 102.1 \mathrm{mg} \mathrm{C} \mathrm{m}^{-2} \mathrm{~d}^{-1}\right)$. Using a study period of 35 days for ArcticNet-Malina, this yielded a cumulated GPP of $3.1 \pm 3.6 \mathrm{~g} \mathrm{C} \mathrm{m}^{-2}$. It also provided a total GPP for the whole study region of $\sim 437.6 \times 10^{3} \mathrm{tC}$, which was roughly twice the total organic carbon delivery (POC + DOC) by the Mackenzie and Anderson River $\left(\sim 241.2 \times 10^{3} \mathrm{tC}\right)$ from 20 July to 24 August 2009.

The ratios of new production to total GPP ( $f$ ratio, as based on nitrate and ammonium uptake) were relatively low in the surface layer $(\sim 0.2)$, except close to Cape Bathurst $(\sim 0.4)$ and near the Mackenzie River delta $(\sim 0.6)$, which reflected localized sources of nitrate from upwelling and riverine input, respectively (Fig. 7c). Below the surface mixed layer, $f$ ratios were also very variable, but relatively high $f$ ratios (>0.6) were found along the Alaskan coast, close to Cape Bathurst and at few locations offshore (Fig. 7d). At some stations west of the Mackenzie Canyon and on the outer eastern shelf, diatoms overwhelmingly dominated (> 80\%) phytoplankton biomass. At stations where the abundance of diatoms was low, autotrophic flagellates dominated the phytoplankton assemblage (not shown).

Further details on the geographic and vertical variability of phytoplankton biomass $(B)$ and production $(P)$ are presented in Table 1. This enables us to calculate an ensemble of $P: B$ ratios. Highest $P: B$ ratios (up to $\sim 41 \% \mathrm{~d}^{-1}$ ) were found within the surface mixed layer, whereas $P: B$ ratios found in association with subsurface productivity were 5-10 times lower (Table 1). 

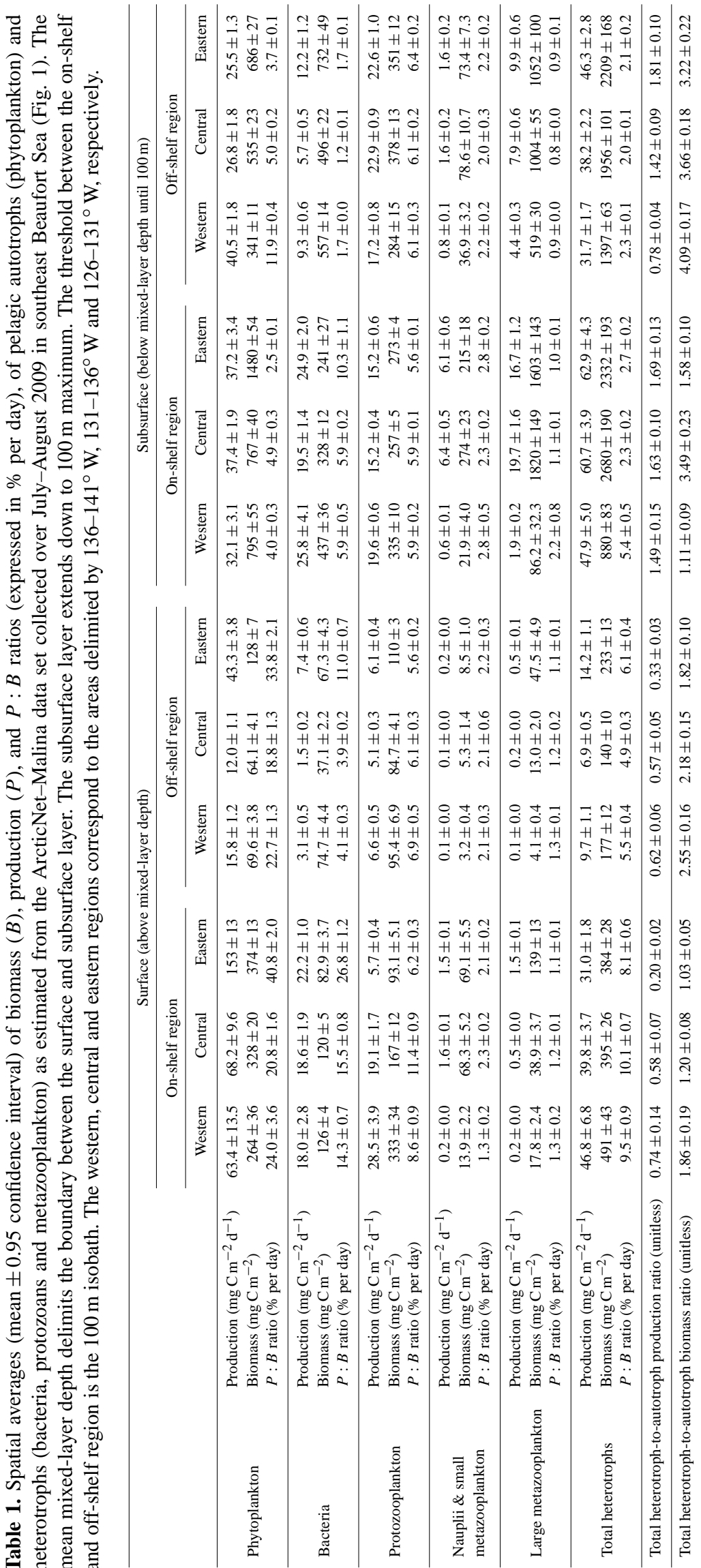

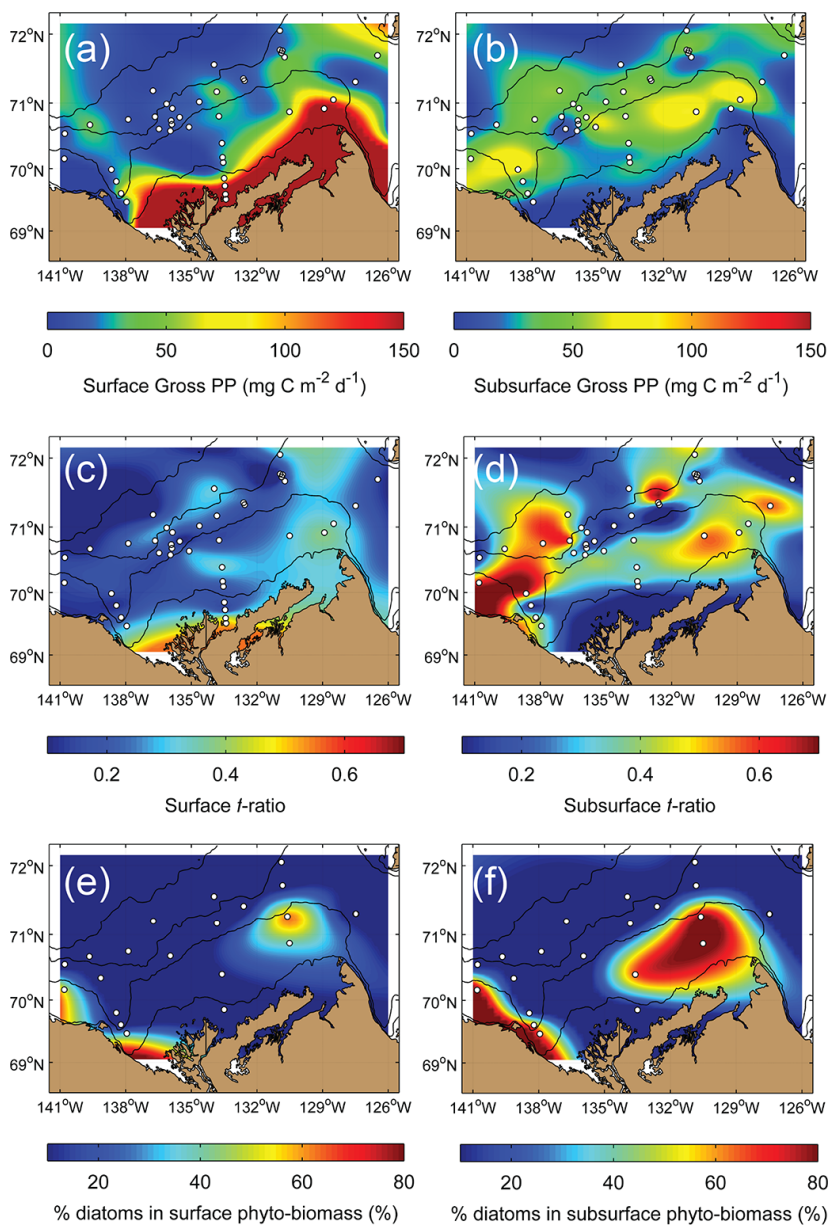

Figure 7. Gridded composites of variables related to phytoplankton dynamics as measured in the surface and subsurface layer of the study region: (a, b) total gross primary production (PP) from field measurements, $(\mathbf{c}, \mathbf{d})$ the $f$ ratio of new PP to total PP as estimated on the basis of nitrate and ammonium uptake incubations, and (e, f) the percentage of diatoms in the total phytoplankton biomass. The white dots correspond to the sampling sites. Bathymetric contours are $20,100,1000$, and $2000 \mathrm{~m}$.

\subsection{Biomass, production and respiration of bacteria, zooplankton and benthos}

Estimates (and $95 \%$ confidence intervals) of biomass and secondary production of pelagic heterotrophs are listed in Table 1 . Secondary production within the surface layer was equally dominated by protozoans ( $48 \%$ ) and bacteria (47\%), while metazooplankton (sum of the two size-fractions) accounted for $5 \%$. Below the surface layer, metazooplankton represented $28 \%$ of the secondary production, whereas bacteria and protozoans contributed on the average to 33 and $39 \%$, respectively. Relative biomass of heterotrophs in the surface layer was more homogenous than their production (i.e., protozoans $48 \%$, bacteria $29 \%$, metazooplankton, $24 \%$ ). Below the surface, protozoans and bacteria accounted for 16 and $24 \%$, while metazooplankton dominated the total heterotroph biomass at $60 \%$. It is worth mentioning that the biomass of metazooplankton was roughly $300 \%$ greater in the central and eastern zones than in the western region of the study area, which was affected by the Mackenzie River plume. A spatial match between the biomass of metazooplankton and phytoplankton was detected in the eastern onshelf subsurface layer where these two groups accounted for $87 \%$ of the whole plankton biomass.

Unsurprisingly, bacteria and protozooplankton had higher $P: B$ ratios (range $\sim 1.2-26.8 \% \mathrm{~d}^{-1}$ ) than metazooplankton (range $\sim 0.8-2.8 \% \mathrm{~d}^{-1}$ ), likely because of their low structural carbon content (i.e., high carbon turnover capacity). The highest bacterial $P: B$ ratio $\left(\sim 26.8 \% \mathrm{~d}^{-1}\right)$ was found in the surface layer of the eastern on-shelf region, while the production of protozoans relative to their biomass was strongest $\left(\sim 11.4 \% \mathrm{~d}^{-1}\right)$ in the central on-shelf zone. Interestingly, the $P: B$ ratios of protozoans was ca. 3 times higher than that of bacteria in the subsurface layer off the shelf, contrary to what was seen in other areas (Table 1).

The gridded maps of respiration fluxes (Fig. 8) complemented the biomass and production data of Table 1 by providing an overview of the spatial variability of heterotrophic activity. When averaged over the whole study area (see definition in Sect. 2.7), respiration outflows from bacteria in the surface and subsurface layers $(48 \pm 44$ and $87 \pm 88 \mathrm{mg} \mathrm{C} \mathrm{m}^{-2} \mathrm{~d}^{-1}$, respectively) were both statistically greater (Mann-Whitney $U$ test, $p<0.001$ ) than those of protozoans ( $23 \pm 30$ and $38 \pm 14 \mathrm{mg} \mathrm{C} \mathrm{m}^{-2} \mathrm{~d}^{-1}$, respectively), which were themselves both statistically higher (same test and $p$ value) than those of total metazooplankton $(2 \pm 3$ and $23 \pm 21 \mathrm{mg} \mathrm{C} \mathrm{m}^{-2} \mathrm{~d}^{-1}$ ). Therefore, an interesting feature that we can discern from the respiration maps is the emergence of an anti-correlation pattern between respiration by bacteria and respiration by protozoans (Fig. $8 \mathrm{a}$ and b vs. Fig. 8c and d); and between respiration by protozoans and respiration by metazooplankton (Fig. 8c and d vs. Fig. 8e and f). For example, protozoan activity was high in the Mackenzie River delta, a zone where bacterial respiration was surprisingly low. Similarly, protozoan respiration was low on the central and eastern shelf, exactly where metazooplankton activity was greatest.

Estimates of benthic respiration on the shelf (derived from field measurements) are presented in Fig. 9. Respiration rates were converted to production rates, which yielded values ranging from $15-40 \mathrm{mg} \mathrm{C} \mathrm{m}^{-2} \mathrm{~d}^{-1}$. Further estimates of epifaunal benthic biomass on the shelf (using an empirical model, see Sect. 2.6) lead to a range of $\sim 3.4-8.9 \mathrm{~g} \mathrm{C} \mathrm{m}^{-2}$. This implies that, on the average, benthic biomass was at least more than twice $\left(\sim 5.9 \mathrm{~g} \mathrm{C} \mathrm{m}^{-2}\right)$ the cumulated biomass of pelagic heterotrophs in the surface and subsurface layers on the shelf $\left(\sim 2.4 \mathrm{~g} \mathrm{C} \mathrm{m}^{-2}\right)$, although pelagic organisms overwhelmingly dominated $(\sim 88 \%)$ total respiration fluxes (Fig. 9). 

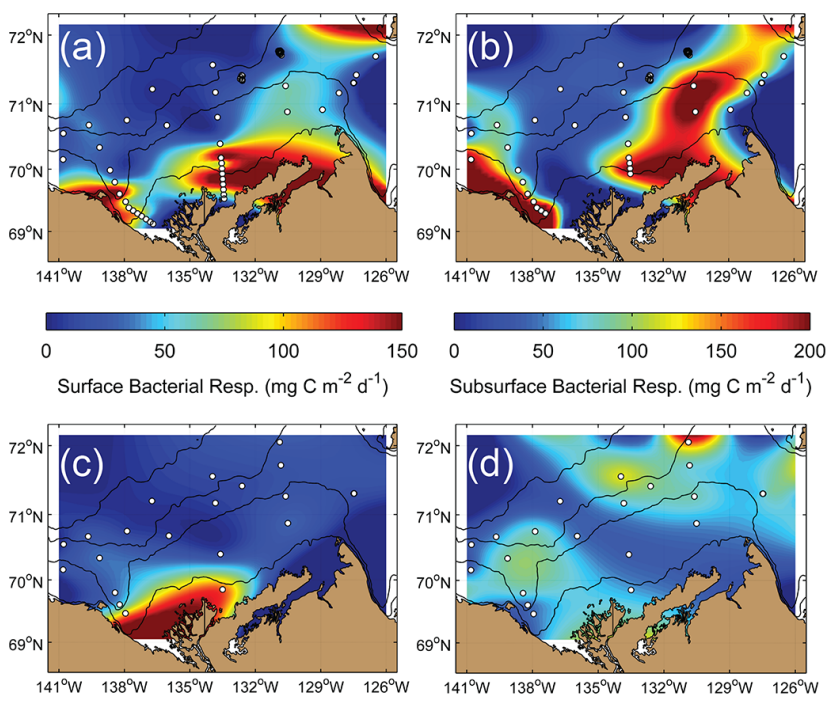

$\begin{array}{llllll}20 & 40 & 60 & 80 & 100 & 120\end{array}$ Surface Protozoo. Resp. $\left(\mathrm{mg} \mathrm{C} \mathrm{m}^{-2} \mathrm{~d}^{-1}\right)$

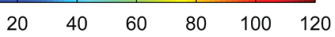
Subsurface Protozoo. Resp. ( $\mathrm{mg} \mathrm{C} \mathrm{m}^{-2} \mathrm{~d}^{-1}$ )
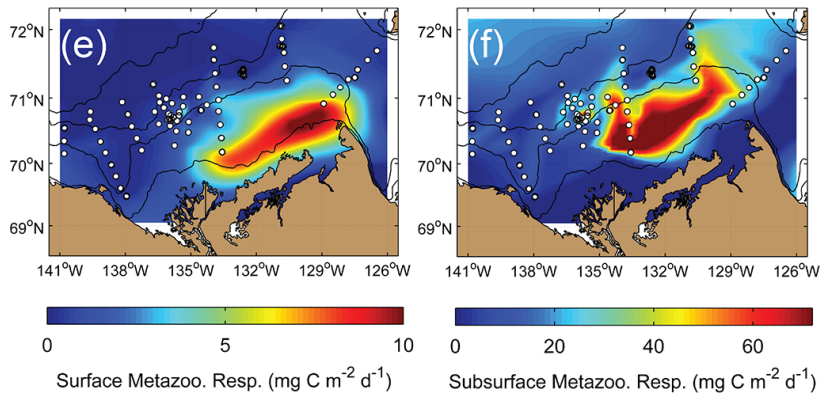

Figure 8. Gridded composites of estimated values related to heterotroph respiration in the surface (left panels) and subsurface (right panels) layer: (a, b) bacterial respiration, $(\mathbf{c}, \mathbf{d})$ protozooplankton respiration, and $(\mathbf{e}, \mathbf{f})$ metazooplankton respiration. The white dots correspond to the sampling stations upon which respiration estimates were calculated. For a detailed description on how each respiration flux has been estimated, please see Sect. 2.6.

\subsection{Ecosystem metabolic balance and net community production estimates}

The ecosystem metabolic balance, as being defined as the interplay between GPP and CR, is depicted schematically in Fig. 9 and via the surface and subsurface gridded maps of Fig. 10. The cross-shelf averages of GPP and respiration outflows (Fig. 9) aim at simplifying the large spatial variability presented in Figs. 7 and 8. As seen above, bacteria dominated the overall organic carbon remineralization across the study region, but protozoans were important players near the Mackenzie River delta and beyond the shelf break. The importance of metazooplankton was only really noticed in the subsurface layer of the central and eastern regions (Fig. 9b and c).
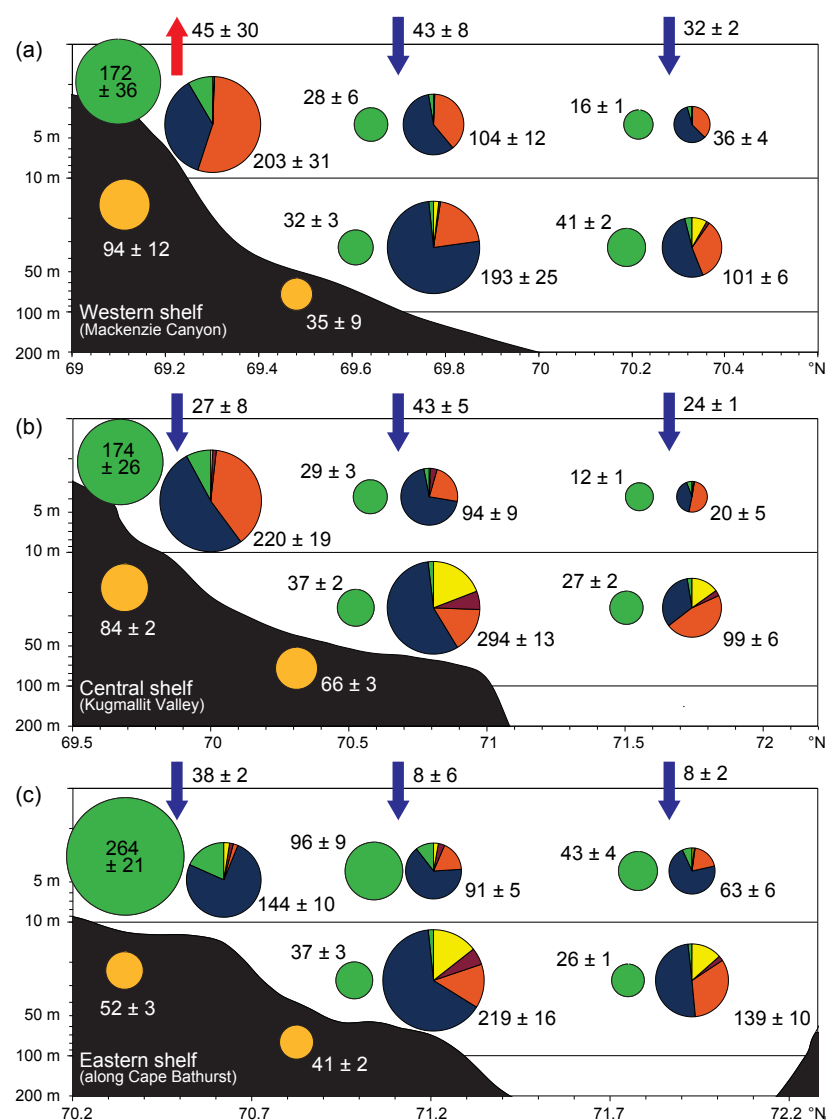

Figure 9. Cross-shelf average estimates (mean \pm 0.95 confidence interval) of gross primary production (green circles), total pelagic heterotroph respiration (pie charts), benthic respiration (orange circles in the sediment), and sea-to-air $\mathrm{CO}_{2}$ fluxes (red and dark blue arrows; same as in Fig. 4). Every pie chart represents the combined respiration of phytoplankton (green), bacteria (dark blue), protozooplankton (dark orange), small metazooplankton and nauplii (dark red), and large metazooplankton (yellow). All units are in $\mathrm{mg} \mathrm{C} \mathrm{m}^{-2} \mathrm{~d}^{-1}$. The western, central and eastern regions correspond to the areas delimited by $136-141^{\circ} \mathrm{W}, 131-136^{\circ} \mathrm{W}$ and 126 $131^{\circ} \mathrm{W}$, respectively (Fig. 1). For a detailed description on how each variable has been estimated, please see Sects. 2.5 and 2.6.

Generally, respiration in the surface mixed layer exceeded GPP, which resulted in the NCP map shown in Fig. 10a. Surface NCP was clearly positive only near to shore and around Cape Bathurst, where increased GPP has been estimated through both remote sensing (Fig. 3f) and in situ field measurements (Fig. 7a). However, surface NCP was close to zero and/or slightly positive in some regions affected by the persistent presence of sea ice (Fig. 3b). Below the surface layer down to $100 \mathrm{~m}$ depth, NCP was negative everywhere (Fig. 10b) with a signal dominated by BR (Fig. 8b). When averaged for the whole region, NCP in the surface and subsurface layer was $-22.6 \pm 70.6 \mathrm{mg} \mathrm{C} \mathrm{m}^{-2} \mathrm{~d}^{-1}$ and $-142.4 \pm 109.4 \mathrm{mg} \mathrm{C} \mathrm{m}^{-2} \mathrm{~d}^{-1}$, respectively. 

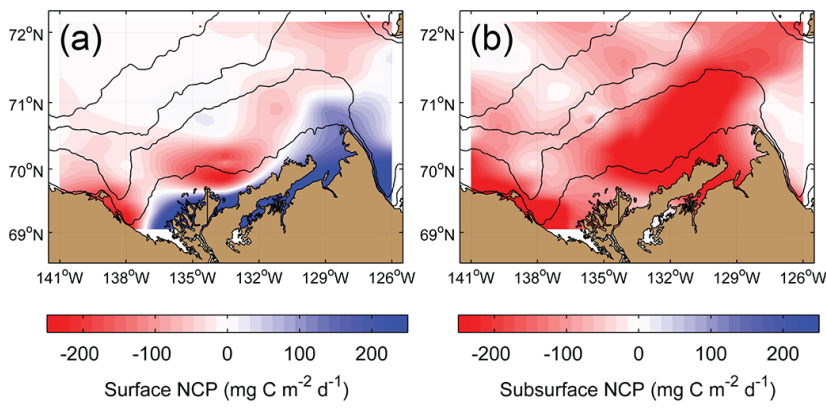

Figure 10. Maps of net community production (NCP) in the (a) surface and (b) subsurface layer of the study area as based on total gross primary production minus total community respiration. The subsurface NCP accounts for the respiration flux from the benthos (over the shelf only, i.e., until the $100 \mathrm{~m}$ isobath). The mean mixedlayer depth delimits the boundary between the surface and subsurface layer; and the subsurface layer extends down to $100 \mathrm{~m}$ maximum. Bathymetric contours are 20,100,1000, and $2000 \mathrm{~m}$.

Model II regressions of NCP against GPP for all the cells contained in the distinct regions provided estimates of threshold GPPs in the surface layer (Fig. 11). We did not attempt any regression of NCP against GPP for subsurface values, as NCP was always negative in the subsurface layer. Threshold GPPs were much higher on the shelf than offshore, with a maximum value of $152 \pm 7 \mathrm{mg} \mathrm{C} \mathrm{m}^{-2} \mathrm{~d}^{-1}$ in the region influenced by the Mackenzie River plume. Lowest threshold GPP $\left(20 \pm 1 \mathrm{mg} \mathrm{C} \mathrm{m}^{-2} \mathrm{~d}^{-1}\right)$ was found in the central off-shelf region where both NCP and GPP were also very low. The only region where a threshold GPP could not be estimated was the western off-shelf region barely characterized by any positive $\mathrm{NCP}$ values (Fig. 11b).

\section{Discussion}

\subsection{To what extent were sea-to-air $\mathrm{CO}_{2}$ fluxes coupled with surface mixed layer NCP?}

Computations of air-sea $\mathrm{CO}_{2}$ exchange in regions affected by strong environmental variability, such as continental margins, require a high-resolution data set of $\Delta p \mathrm{CO}_{2}$ (Anderson et al., 2010). A location-by-location approach (Else et al., 2012) is particularly needed in Arctic shelf seas where multiple physical, geochemical and biological processes influence air-sea $\mathrm{CO}_{2}$ exchange (e.g., photosynthesis, respiration, vertical mixing, upwelling, surface warming and cooling, lateral advection, ice melt and formation, as well as river runoff). Air-sea $\mathrm{CO}_{2}$ fluxes in the southeast Beaufort Sea were previously documented by Mucci et al. (2010), Shadwick et al. (2011), and Else et al. (2013a, b), but none of these studies had the fine-scale geographical coverage that the ArcticNetMalina 2009 sampling strategy provided across the Mackenzie Shelf and slope.
That being said, our results generally corroborate the pattern in air-sea $\mathrm{CO}_{2}$ fluxes deciphered for the region in summer. First, we estimated a weak net sink of $-2.0 \mathrm{mmol} \mathrm{C} \mathrm{m}^{-2} \mathrm{~d}^{-1}$, a mean value close to the ones obtained by Mucci et al. (2010) and Else et al. (2013a) (i.e., -2.3 and $-2.4 \mathrm{mmol} \mathrm{C} \mathrm{m}^{-2} \mathrm{~d}^{-1}$, respectively). These mean rates were, however, much lower (in terms of sink) than the air-sea flux of Shadwick et al. (2011) who estimated an average sink of $-7.2 \mathrm{mmol} \mathrm{C} \mathrm{m}^{-2} \mathrm{~d}^{-1}$ for July-August 2008. While the study area of Shadwick et al. (2011) was a small box in Amundsen Gulf unaffected by $\mathrm{CO}_{2}$ outgassing from both river input and upwelling of $\mathrm{CO}_{2}$-rich waters at Cape Bathurst, this value may also have been biased towards $\mathrm{CO}_{2}$ uptake due to undersampling. Using a higher-resolution data set of $\Delta p \mathrm{CO}_{2}$, Else et al. (2013b) observed that the Amundsen Gulf shifted from a weak source to a weak sink of $\mathrm{CO}_{2}$ over the July-August time period, with a mean value around $-2.5 \mathrm{mmol} \mathrm{Cm}^{-2} \mathrm{~d}^{-1}$. In our study, we observed similarly to Else et al. (2013b) - that the Amundsen Gulf was near equilibrium or was slightly outgassing $\mathrm{CO}_{2}$ to the atmosphere, potentially due to warming, net heterotrophy or upwelling. The exact factor or combination of factors that stimulated such a weak outgassing in Amundsen Gulf during our survey remains elusive, however.

Second, we identified a sharp transition from a $\mathrm{CO}_{2}$ source to a $\mathrm{CO}_{2}$ sink when transiting away from the Mackenzie River delta. This shift was previously detected through snapshot measurements of $p \mathrm{CO}_{2}$ (cf. Vallières et al., 2008; Mucci et al., 2010; Else et al., 2012), but our mapping of air-sea $\mathrm{CO}_{2}$ fluxes clearly defined the transition zone. Interestingly, the mid-shelf area bordering the zone of $\mathrm{CO}_{2}$ outgassing in the delta was the sub-region characterized by the strongest $\mathrm{CO}_{2}$ sink (Fig. 4f), suggesting that PP combined with riverine freshwater diluted into cold oceanic waters acted synergistically to facilitate $\mathrm{CO}_{2}$ uptake. Third, the coastal area west of Herschel Island (Fig. 1) was identified as a small zone supersaturated in $\mathrm{CO}_{2}$ and acting as a source of $\mathrm{CO}_{2}$. This area exactly matches the one where Mathis et al. (2012) detected $\mathrm{CO}_{2}$ supersaturation during a cruise in October 2011, when strong easterly winds prevailed in coastal Beaufort Sea as a result of an intensified atmospheric pressure gradient between the Beaufort Sea High and an Aleutian low. Actually, Williams and Carmack (2008) previously identified this area as often affected by shelf-break upwelling developing in the Mackenzie Canyon owed to isobath divergence on the northeastern side of Herschel Island.

Fourth, we detected a localized zone of strong $\mathrm{CO}_{2}$ outgassing on the northeastern shelf break, which corresponds to the region nearby Cape Bathurst now well known to be sensitive to wind-driven coastal upwelling (Williams and Carmack, 2008; Mucci et al., 2010; Tremblay et al., 2011; Else et al., 2012). What was indeed different here was the configuration of the patch of increased $f \mathrm{CO}_{2} \mathrm{SW}$ (Fig. 4e), which was more spatially limited when compared to what Else et al. (2012) observed in the fall of 2007 during a massive 
(a)

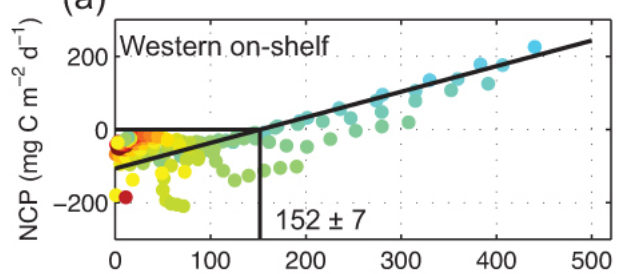

(c)

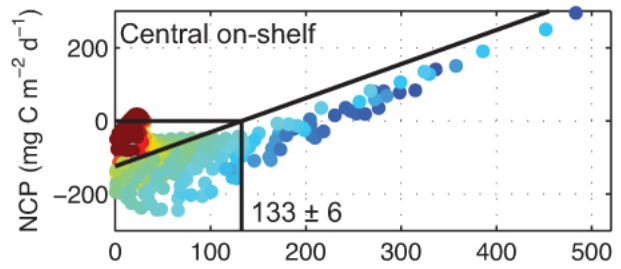

(e)

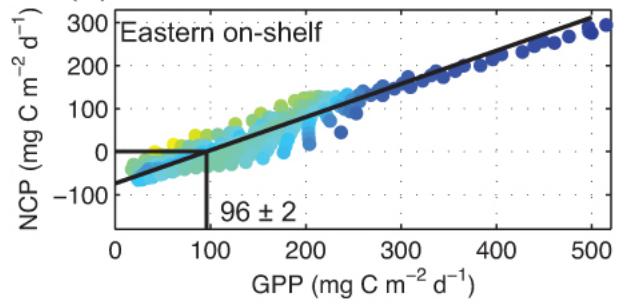

(b)

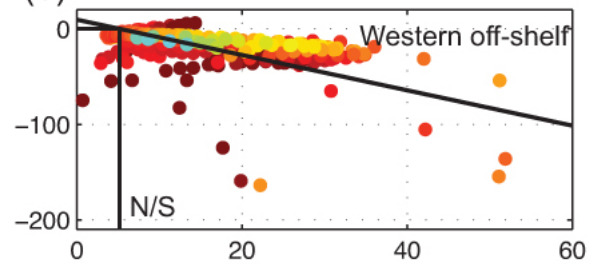

(d)

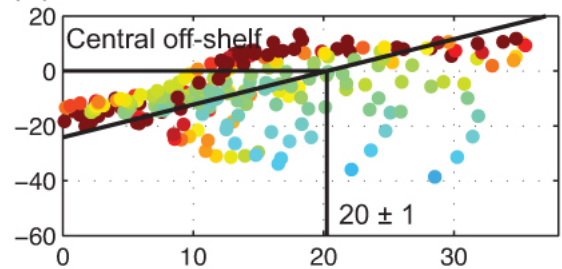

(f)

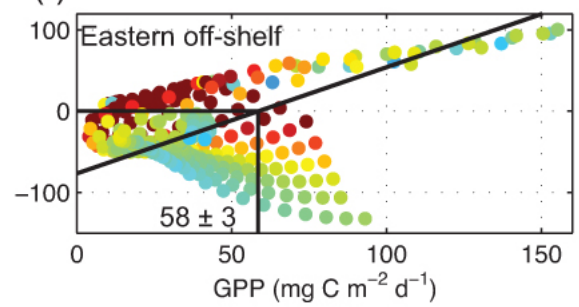

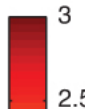

2.5

2

1.5

1

0.5

H/A Ratio

Figure 11. Model II regressions of net community production (NCP) against gross primary production (GPP) in the surface layer of the on-shelf and off-shelf zones (delimited by the $100 \mathrm{~m}$ isobath). Every dot represents a pixel extracted from the gridded composites and further colored according to the total heterotroph to autotroph biomass ratio $(H / A$ ratio). The threshold GPP (i.e., GPP at which NCP becomes positive) is showed on every image, except for the western off-shelf area where the regression was not significant (N/S). The western, central and eastern regions correspond to the areas delimited by $136-141^{\circ} \mathrm{W}, 131-136^{\circ} \mathrm{W}$ and $126-131^{\circ} \mathrm{W}$, respectively (Fig. 1).

upwelling event, and which was slightly larger and displaced to the north relative to what Mucci et al. (2010) observed during the relatively quiescent summer of 2004 (when compared to 2008 for example; see Tremblay et al., 2011). This underscores that, although the eastern Mackenzie Shelf along Cape Bathurst is frequently affected by upwelling events, the exact pattern of $\mathrm{CO}_{2}$ outgassing is obviously dictated by the persistence and direction of winds (i.e., pattern of Ekman transport), but also by the balance between PP and total community respiration. However, quantifying the precise contribution of each physical and biological factor that modulates air-sea $\mathrm{CO}_{2}$ exchange remains a challenging task, especially since various timescales are involved with respect to ocean circulation and ecosystem response.

One way to explore to what extent sea-to-air $\mathrm{CO}_{2}$ fluxes were coupled with ecosystem metabolism during Malina is to actually sum up surface $\mathrm{NCP}$ and $\mathrm{CO}_{2}$ fluxes. Following such an addition, the positive values would mean that the potential for $\mathrm{CO}_{2}$ sink due to a positive NCP (net autotrophy) was dampened by external forcings that increased $p \mathrm{CO}_{2} \mathrm{SW}$ at the surface (e.g., upwelling of $\mathrm{CO}_{2}$-rich waters, warming/evaporation, photomineralization), while negative values would mean that the potential for a given zone to be a $\mathrm{CO}_{2}$ source due to negative NCP (net heterotrophy) was compen- sated by other factors that lowered $p \mathrm{CO}_{2} \mathrm{SW}$ (e.g., cooling, downwelling, dilution, inherent low $p \mathrm{CO}_{2}$ ). This new metric, as mapped on Fig. 12, illustrates that most of the study region was affected by factors lowering $p \mathrm{CO}_{2} \mathrm{SW}$, which were somehow counteracting the net heterotrophy that generally prevailed across the southeastern Beaufort Sea during July-August 2009. This situation remained even when taking into account the range of possible $\mathrm{CO}_{2}$ fluxes and NCP estimates resulting of error propagation. The main factor that could explain the discrepancy between metabolic balance and $\mathrm{CO}_{2}$ exchange is likely the strong PP that developed over the shelf prior to the field campaign, as measured with ocean color remote sensing (Fig. 3e). Since it takes several months for gas exchange to replace $\mathrm{CO}_{2}$ uptake driven by $\mathrm{PP}$ (cf. Else et al., 2013a), it is not surprising that $p \mathrm{CO}_{2} \mathrm{SW}$ was still undersaturated at the time of our study. These findings also imply that mechanisms favoring carbon export below the surface mixed layer before and during Malina were greater than the potential for organic carbon remineralization near the surface. Indeed, amazingly high vertical POC fluxes (up to $>5000 \mathrm{mg} \mathrm{C} \mathrm{m}^{-2} \mathrm{~d}^{-1}$; Forest et al., 2013, see also Fig. 5) were detected in the neritic zones affected by the most negative values in Fig. 12. On the shelf, vertical export during July-August was roughly one order of 

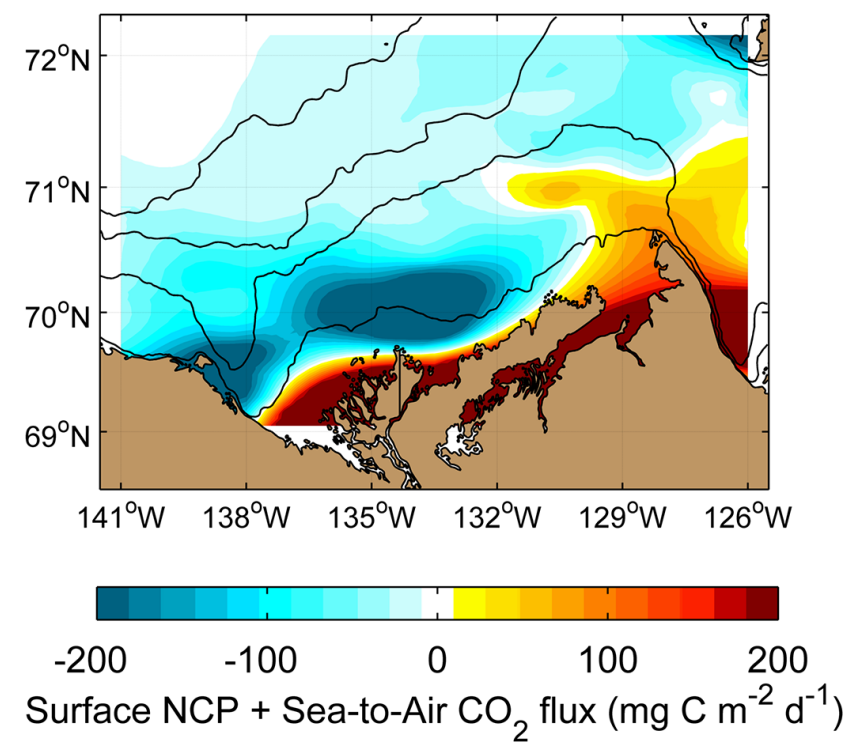

Figure 12. Map of the sum of surface net community production (NCP) and sea-to-air $\mathrm{CO}_{2}$ fluxes for the ArcticNet-Malina campaign of mid-summer 2009. This map aims at showing the spatial discrepancy between $\mathrm{CO}_{2}$ fluxes and ecosystem metabolism. A positive value (reddish) means that the potential for $\mathrm{CO}_{2}$ sink due to positive NCP is dampened by external forcings (e.g., upwelling of $\mathrm{CO}_{2}$-rich waters, warming, photomineralization). While negative values (turquoise) mean that the potential for $\mathrm{CO}_{2}$ source due to negative NCP is compensated by other factors (e.g., past productivity and vertical export, dilution, cooling). Bathymetric contours are $20,100,1000$, and $2000 \mathrm{~m}$.

magnitude greater than the total community respiration estimate $\left(\sim 250 \mathrm{mg} \mathrm{C} \mathrm{m}^{-2} \mathrm{~d}^{-1}\right)$. Of course, the system can be expected to equilibrate over time as the decrease in nutrients and light availability progressively limits PP, while heterotrophs continue to remineralize organic carbon previously brought by PP and river inputs. This temporal lag between $\mathrm{CO}_{2}$ exchange and heterotrophic respiration probably explains why Else et al. (2013a) did not measure particularly low $p \mathrm{CO}_{2} \mathrm{SW}$ values across the Mackenzie Shelf (300$370 \mu \mathrm{atm})$ just after our field survey.

Given the oligotrophic nature of the central Arctic Basin (e.g., Ardyna et al., 2013), the main factor explaining any decoupling between NCP and air-sea $\mathrm{CO}_{2}$ fluxes beyond the shelf was rather surface dilution by sea ice meltwater, which causes a reduction in surface $p \mathrm{CO}_{2}$ (e.g., Denman et al., 2011). By contrast, the most positive values in Fig. 12 were restrained to the very nearshore environment and to the region around Cape Bathurst, which were thus affected by factors diminishing the net autotrophy of these zones (Fig. 10a). Along Cape Bathurst, it appears now evident (cf. Mucci et al., 2010; Else et al., 2012) that the enhanced upwelling that develops in this area is able to bring enough $\mathrm{CO}_{2}$ to reduce the potential for $\mathrm{CO}_{2}$ uptake through PP and export. Of course, this would be true only if the timescale is long enough (e.g., several days to weeks) to discern the net result of successive biophysical events. Interestingly, the balance in air-sea $\mathrm{CO}_{2}$ exchange near Cape Bathurst shifted from a sink to a source only in a localized patch apparently characterized by no substantial PP prior to Malina (based on remote sensing, see area $71^{\circ} \mathrm{N}, 131^{\circ} \mathrm{W}$ in Fig. 3e). This suggests that as a general rule, $\mathrm{CO}_{2}$ outgassing related to wind-driven upwelling across the Mackenzie Shelf (or at least the "kind" of upwelling observed in summer 2009) can be compensated by PP through $\mathrm{CO}_{2}$-fixation, if a concomitant upward flux of nitrate favors the new production of large and rapidly sinking diatoms (Fig. 7e and f). An analogue situation appeared to prevail near the coast where the impact of very high PP rates on $\mathrm{NCP}$ was attenuated by excess $\mathrm{CO}_{2}$ outgassed from riverine waters leaving the inner estuary. This peculiar feature of continental shelves influenced by major riverine inputs was recently underscored in the review of Chen et al., 2012.

\subsection{What was the interplay between upwelling, river plume and sea ice in driving $\mathrm{C}$ fluxes?}

The common view on upwelling in the Beaufort Sea is one that would induce the replacement of the warm upper-layer water over the shelf by colder nitrate-rich water from the intermediate Pacific-derived water layer (e.g., Williams and Carmack, 2008; Tremblay et al., 2011; Pickart et al., 2013). Here, we did not observe any features in sea surface temperature that could have informed us on the presence of an upwelling reaching the surface (Fig. $4 \mathrm{~b}$ ). Cross-shelf nitrate sections rather showed that the on-shelf flux was a terrain-following pattern with variable penetration and intensity. Given that the dominant wind pattern in summer 2009 was a strong northerly flow followed by weak easterlies (Fig. 3), the resulting Ekman transport of surface waters to the west-northwest would have favored the entrainment of subsurface waters to the east-southeast. Although the true south-eastward (up-the-shelf) component of the subsurface flow was likely not very strong in this situation, it was thus sufficient enough to bend isopycnals and bring nitrate into the lower euphotic zone over the shelf (see also Tremblay et al., 2013). The slanting of deep waters across the shelf was evident everywhere, except at the transect 400 visited at the end of the campaign, which reflected the development of a cyclonic regime over August (NSIDC, 2009) and the subsequent relaxation of isopycnals. This is in accord with Williams and Carmack (2008) who demonstrated that upwelling is a broad circulation pattern over the entire Canadian Beaufort Shelf that leads to topographically intensified upwelling at Cape Bathurst and in the Mackenzie Canyon. Intrusion of nitrate-rich waters over a sloping bottom also supports our pattern in gross PP, which predominantly occurred at depth on the mid-to-outer shelf, and enhanced at surface on the inner-to-mid shelf. Based on our $f$ ratios, we can roughly estimate that the increased PP rates observed near the coast were fueled at $\sim 30 \%$ by nitrate advected laterally 
from offshore. In the Mackenzie River delta, an additional $30 \%$ of the PP was apparently supported by nitrate coming from the Mackenzie River itself ( $f$ ratio $\approx 0.6$ ).

Under the effect of the west-northwest surface water circulation, the relatively intense surface PP rates measured nearshore would lead to the transport, aggregation and sinking of phytoplankton in the mid-to-outer shelf regions. In fact, this is exactly what we estimated based on our field measurements. Phytoplankton biomass (dominated by diatoms up to $>80 \%$ ) was greatest in the subsurface layer over the outer shelf $\left(\sim 767-1480 \mathrm{mg} \mathrm{C} \mathrm{m}^{-2}\right)$, also in agreement with the POC inventories that were highest in this water layer (Fig. 5). Further propagation of this seaward, descending flux would lead to the sinking of large phytodetritus over the slope. An oblique flux of large particles is precisely what we observed at the eastern shelf break and in the vicinity of the Mackenzie canyon within a previous study on vertical POC fluxes during Malina (Forest et al., 2013). Furthermore, the longitudinal gradient in POC concentration (increasing inventories from west-to-east, following phytoplankton biomass) is another confirmation that autochthonous processes govern the overall particulate carbon cycling over the Mackenzie Shelf despite some very large riverine inputs (cf. Macdonald et al., 1998; O'Brien et al., 2006; Tolosa et al., 2013).

With the influence of northerly/easterly winds resulting from a predominant high-pressure system (anticyclonic Beaufort Sea High) in early summer 2009, the river plume expanded to the west-northwest, leaving potentially the eastern Mackenzie Shelf and Amundsen Gulf unaffected by substantial freshwater and terrigenous inputs. In fact, in regions where surface salinity was above 25.5 in our study (Fig. 4a), the percentage of Mackenzie River water in surface waters averaged only $4.7 \% \pm 2.1 \%$ (Lansard et al., unpublished data; see also Tremblay et al., 2013). This view contrasts with the results of Fichot et al. (2013) presenting the southern Beaufort Sea as a region plagued with terrigenous DOC (see their Fig. 3) as based on the spectral slope of CDOM which is correlated to lignin phenols. This illustrates that even less than $5 \%$ of river water containing high CDOM concentration can make the terrigenous fraction still dominating the spectral signature. This nonetheless provides insights on the transport and quality of the terrigenous organic matter delivered on Arctic shelves. In the Beaufort Sea, particulate matter from the Mackenzie River sinks quasi-exclusively ( 97\%) near the coast (O'Brien et al., 2006; Magen et al., 2010), thus rapidly excluded from remineralization processes within the shallow surface mixed layer; while riverine-dissolved organic matter in the region (presumably dominated by highly degraded "refractory" lignin carbon; Goñi et al., 2000) appears to be of limited bioavailability as based on its amino acid content (Shen et al., 2012). This likely explains why the Mackenzie Shelf is systematically described as a sink for atmospheric $\mathrm{CO}_{2}$ (e.g., Mucci et al., 2010; this study). By contrast, on large Siberian shelves, the decomposition of a more labile terrestrial organic matter near the surface induces an excess of DIC that is expected to be outgassed to the atmosphere (Anderson et al., 2009). Indeed, Vonk et al. (2013) determined that DOC derived from ancient carbon permafrost in coastal Siberia is highly biolabile as based on DOC losses during incubation experiments. Hence, understanding the routing and quality of terrestrial matter delivered to the Arctic Ocean is as important as monitoring the quantity of the load at discrete source points.

Assuming that the eastern Mackenzie Shelf during our study was not affected by substantial riverine inputs implies conversely a difficult interpretation of our remotely sensed estimates of PP (Fig. 3e and f). On the one hand, CDOM contaminated the phytoplankton signal everywhere on the inner shelf and west of the Mackenzie Canyon (Matsuoka et al., 2013), potentially leading to overestimations of PP as based on satellite imagery. On the other hand, the patterns in PP measured in situ at the ocean surface and the MODIS-derived PP estimates during the period from 20 July to 24 August were surprisingly similar, suggesting that remote sensing is indeed suitable for estimating PP over this shelf. However, linear regression of net PP measured in situ against PP estimated with ocean color during that period revealed that MODIS roughly overestimated PP by a factor of 2.3-2.7 $\left(r^{2}=0.3\right)$ due to an overestimation of chl owed to CDOM (Ben Mustapha et al., 2012). In any case, an important fact to underscore is that the area, with high PP levels, and the Mackenzie River plume were fully intertwined (see also Tremblay et al. (2013) for a detailed discussion on the geographical variability of PP during Malina). With the aim of evaluating to which extent the Mackenzie River supported PP during Malina, we can use the recent budget of Le Fouest et al. (2013). Using a concentration of $3.8 \mathrm{mmol}$ nitrate $\mathrm{m}^{-3}$ and the cumulated runoff of the Mackenzie River for our 35-day sampling period, this yields a cumulative flux of $\sim 2.4 \times 10^{3} \mathrm{tN}$. When converted into carbon production using a $\mathrm{C}: \mathrm{N}$ ratio of 8 (Tremblay et al., 2008) and a mean $f$ ratio of 0.6 (as recorded near the Mackenzie Delta), this provides a total GPP of $32 \times 10^{3} \mathrm{tC}$, which is about $7.4 \%$ of the total GPP measured in situ during ArcticNet-Malina $\left(\sim 437.6 \times 10^{3} \mathrm{tC}\right)$. However, if we compare this river-based estimate to GPP measured only in the region truly affected by the Mackenzie River plume (i.e., western shelf and slope; where GPP $\approx 114.1 \times 10^{3} \mathrm{tC}$ ), the river plume appears to have supported approximately $28 \%$ of GPP in this area.

With a deep nitracline (Fig. 6), the presence of an ice cover of up to $80 \%$ concentration, and a limited influence of the Mackenzie River nutrient flux, the offshore Canada Basin environment strongly inhibits PP, which limits its capacity as a $\mathrm{CO}_{2}$ sink, and prevents the development of an active herbivorous food web. Indeed, numerous studies demonstrated that PP in the Canada Basin is not expected to increase substantially despite the ongoing sea ice retreat (e.g., Cai et al., 2010; Carmack and McLaughlin, 2011; Bélanger et al., 2013; Else et al., 2013a), and might rather be affected by a progressive 
shift toward the dominance of small cells, microbial looping, and regenerated production ( $\mathrm{Li}$ et al., 2009; Comeau et al., 2011; Codispoti et al., 2013). This trend appears to be induced by an increased surface stratification (which impedes vertical mixing and deepens the nutricline) due to freshwater storage facilitated by an intensified Beaufort Sea High paralleled by an increase in the cyclonic circulation over the Eurasian basins (Timmermans et al., 2011; Morison et al., 2012; Bourgain et al., 2013). In line with these studies, our results suggest that the biogeochemical gradient between the shelf, slope and basin environments in the Beaufort Sea is exacerbated with the ongoing environmental change (i.e., a more productive regime over the shelf vs. a more oligotrophic regime offshore). Hence, a key related issue is now to understand how the structure and metabolism of pelagic and benthic food webs respond and feed back to such an extreme biogeochemical setting.

\subsection{How did the food web respond and feed back to organic and inorganic $\mathrm{C}$ cycling?}

There is no other variable that more effectively connects biogeochemical carbon cycling with food web activities than NCP. It accounts for the balance between PP and respiration, and thus of other metabolic processes in between such as biomass build-up and reproduction. Since NCP is tightly linked with both $\mathrm{CO}_{2}$ and $\mathrm{O}_{2}$ cycling, NCP is typically based on an assertion of $\mathrm{O}_{2}$ dynamics using bottle incubations or geochemical tracers. At the heart of such NCP estimates currently lies a very active debate on the inconsistency between the results of in vitro $\mathrm{O}_{2}$ bottle incubations and in situ $\mathrm{O}_{2}$ / Ar-based mixed-layer NCP, as exhaustively reviewed by Ducklow and Doney (2013). Here, we adopted another approach by summing up respiration rates of food web components, which were subsequently subtracted from gross PP estimates that were also assessed empirically. While our approach has its own uncertainties (e.g., conversion factors, plankton biomass estimates), we are confident that the overall picture of ecosystem metabolism across the complex Arctic shelf system that we sampled was better estimated this way. In fact, assuming a steady state between mixedlayer NCP and sea-to-air fluxes (as the $\mathrm{O}_{2} / \mathrm{Ar}$ methodology requires) would have yielded a wrong portrait of ecosystem metabolism, since the temporal decoupling between autotrophic and heterotrophic processes was obvious. In addition, $\mathrm{O}_{2}$ bottle incubations would have provided only snapshot bulk measurements without having the possibility to verify which food web components were influencing ecosystem metabolism.

Overall, our results support the conclusion of OrtegaRetuerta et al. (2012) that the southeastern Beaufort Sea during Malina was net heterotrophic, but our calculations based on a different strategy enabled us to identify more zones where autotrophy could be observed in the surface mixed layer (Fig. 10a). Ortega-Retuerta et al. (2012) compared bac- terial carbon demand against net PP using a fixed and relatively low BGE of 0.077 , and by integrating values over the whole euphotic layer, which was extending tens of meters below the mixed-layer depth. They found net heterotrophy everywhere, except on the eastern side of the Mackenzie River delta ahead of Tuktoyaktuk. Accordingly, they found a strong imbalance between bacterial carbon demand and PP, most likely because the subsurface layer during Malina contained substantial inventories of organic carbon (Fig. 5) resulting from past PP (as discussed in 4.1). Moreover, BGE is a highly variable parameter $(\sim 0.01-0.4)$ in the Arctic Ocean (e.g., Kirchman et al., 2009; Nguyen et al., 2012) and we surmise that our approach, based on a flexible BGE, embraces this variability. Also, it should be noted that a carbon demand lower than net PP is not necessarily the sign of an unbalanced situation. As summarized by Legendre and Niquil (2013), respiration is the only appropriate metric to assess ecosystem metabolism given that heterotrophic production is not an additive property of food web flows (i.e., the same carbon may be part of both production and respiration). Of course, this does not mean that bacteria were not partly fueled by allochthonous DOC or by local PP supported by riverine nutrients, but it indicates at least that caution should be exerted when comparing snapshot measurements of bacterial carbon demand against PP.

By contributing to ca. $54 \%$ of respiration outflows in the upper $100 \mathrm{~m}$, bacteria were the dominant actor of organic carbon remineralization and drove the most negative values in subsurface NCP. A spatial match between bacterial respiration and high surface DIC concentration could be even discerned over the eastern shelf (Fig. 4d), although high DIC might also result from $\mathrm{CO}_{2}$-rich halocline waters intruding over the shelf bottom. In any case, such observations indicate that the shallow mixed-layer depth in the Beaufort Sea is not an impermeable barrier to turbulent exchange, as suggested by Mucci et al. (2010). This is because a significant fraction of the surface stress can be, in fact, transmitted below the MLD - so that shear production and interaction with existing shear that develops across the mixed layer can occur (Belcher and Grant, 2011). This phenomenon develops preferentially in areas where baroclinic tidal mixing is enhanced by a steep topography, such as in the northeastern corner of the Mackenzie Shelf (Kulikov et al., 2004). When excluding benthic respiration, the contribution of bacteria to pelagic respiration rose to ca. $61 \%$. This percentage is slightly higher than the contribution of bacteria to community respiration measured in the Amundsen Gulf in spring-early summer 2008 ( 45\%; Forest et al., 2011). However, given that the Mackenzie River was expected to influence shelf metabolism and that our study occurred during a late-summer period when the ecosystem was more mature, the contribution of bacteria to respiration outflows was not "that" overwhelmingly dominant. Of key importance in our study was the role of protozoans (e.g., ciliates, heterotrophic dinoflagellates) that apparently showed an anti-correlation pattern with 
bacterial activity (e.g., Fig. 8a-d; Table 1). The contrast between protozoans and bacteria was particularly evident in the Mackenzie River delta and beyond the shelf break. Top-down regulation of bacteria by protozoan grazing in these zones cannot be excluded, but remains difficult to firmly establish. It has been demonstrated that bacteria in Arctic pelagic environments are generally regulated by bottom-up factors, such as carbon and nutrient availability (Garneau et al., 2008; Kirchman et al., 2009; Ortega-Retuerta et al., 2012), and are usually less affected by the weak grazing pressure from heterotrophic protists from spring to autumn (Vaqué et al., 2008; Forest et al., 2011; Sanders and Gast, 2012). Hence, the strength of trophic linkages between bacteria and protozoans remains an open question in our study, especially as strong spatial and seasonal variability appear to affect bacterivory rates in Arctic waters (Bussey, 2003).

Interestingly, we also observed an anti-correlation pattern between metazooplankton and protozoans, suggesting the presence of a trophic cascade in the planktonic food web (i.e., metazoans controlled protozoans who controlled bacteria). Over the eastern shelf where the biomass of metazooplankton was high (mainly dominated by copepods; see Forest et al., 2012), the biomass of protozoans was surprisingly low (Table 1). As a result, the coupling between copepods and diatoms was tight nearby Cape Bathurst (Table 1), supporting previous evidence that the ecological setting of this zone favors trophic transfer to vertebrates (Sampei et al., 2011; Tremblay et al., 2011; Walkusz et al., 2012). Actually, the trophic coupling appears to be catalyzed by the episodic, but frequent, upwelling events that foster the development of diatom production (see Sect. 4.2) and the transport of lipid-rich calanoid copepods from the deep Amundsen Gulf to the eastern Mackenzie Shelf (Walkusz et al., 2012). In particular, such mechanism appears to sustain conditions attractive to bowhead whales that congregate annually on the eastern Mackenzie Shelf. Here, we confirmed this view of a biological hotspot, but we also present signs of a further expansion of the zooplankton biomass toward the central shelf, presumably as a result of the dominant westward flow that developed under the influence of northerly winds. Between the inner and outer shelf $(20-100 \mathrm{~m}$ isobath), vertical POC fluxes (Fig. 5) and benthic carbon turnover (Fig. 9) in the central region were also greater than in the western and eastern areas, suggesting that the strong northerlies that prevailed prior to Malina induced a general displacement of food web activities westward of Cape Bathurst.

Threshold GPPs as estimated from model II regressions between NCP and GPP (Fig. 11) offered further indications that the ecosystem we sampled could not be considered in steady state. In fact, if we had used NCP integrated over the whole euphotic layer, threshold GPPs would have been disproportionately high, with values roughly $2-3$ times higher than what we estimated in the surface mixed layer only. Given the high temporal variability of PP in the Beaufort Sea during summer (Ardyna et al., 2013), it is reasonable to assume that a substantial fraction of net heterotrophy was linked to the ingestion of organic matter produced earlier in the season and not detected by our measurements of PP during the campaign. This could also include marine organic matter freshly deposited on the sea bottom and resuspended by winds or upwelling currents (O'Brien et al., 2006). Over the shelf, the east-to-west increase in threshold GPP can thus be interpreted as the extra-heterotrophic activity supported by DOC and POC from the Mackenzie River. Since threshold GPPs were overall in the same order of magnitude on the eastern shelf (apparently unaffected by the Mackenzie River) than on the western and central zones, we can consider that riverine carbon input did not dramatically increase net heterotrophy, most probably because the river brought also nutrients that fueled GPP. Offshore, threshold GPPs were substantially lower than on the shelf, reflecting the low primary and secondary production occurring in the slope-basin environment (see Fig. 9). In particular, the negative slope computed for the western off-shelf zone represents a patent indication of the low-productive regime that prevailed in the Canada Basin at the time of our study

\section{Summary and implications}

Our study illustrates that the consequences of Arctic changes on marine carbon cycling are not geographically uniform, even at the regional scale. In the attempt to synthesize our observations, we created a schematic that represents the food web structure and environmental forcings that synergistically drive ecosystem metabolism and air-sea $\mathrm{CO}_{2}$ fluxes along the shelf-basin gradient in the Beaufort Sea during summer (Fig. 13). As the atmospheric and sea ice conditions shift in the Arctic in response to global change, the biogeochemical gradient between the shallow shelves and the deep basins is exacerbated. The strengthening of the anticyclonic Beaufort Sea High accompanied by an enlargement of the cyclonic regime over the Eurasian Arctic (i.e., Arctic dipole; Overland et al., 2012) leads to an intensification of easterly-northeasterly winds favorable to on-shelf upwelling and clear sky conditions in the western Arctic. However, during the current transitional phase in sea ice conditions in the Beaufort Sea, large sea ice floes from the central Arctic pack might easily get transported southward, as we observed during July-August 2009 under the effect of strong northerly winds. Hence, when the upwelling-favorable winds are of short duration and/or not very strong (such as in the present study), the so-called upwelling events may take the form of a sloping flux of deep waters across the shelf break and over the shelf bottom, which would never reach the surface except, possibly, in the nearshore zone. In any case, both upwelling and sloping currents bring substantial amount of dissolved $\mathrm{CO}_{2}$ and nutrients upward. Surface outgassing of $\mathrm{CO}_{2}$ over the shelf can be attenuated if the concomitant flux of nitrate boosts PP $\left(\mathrm{CO}_{2}\right.$-fixation $)$ and enhances vertical export - such 

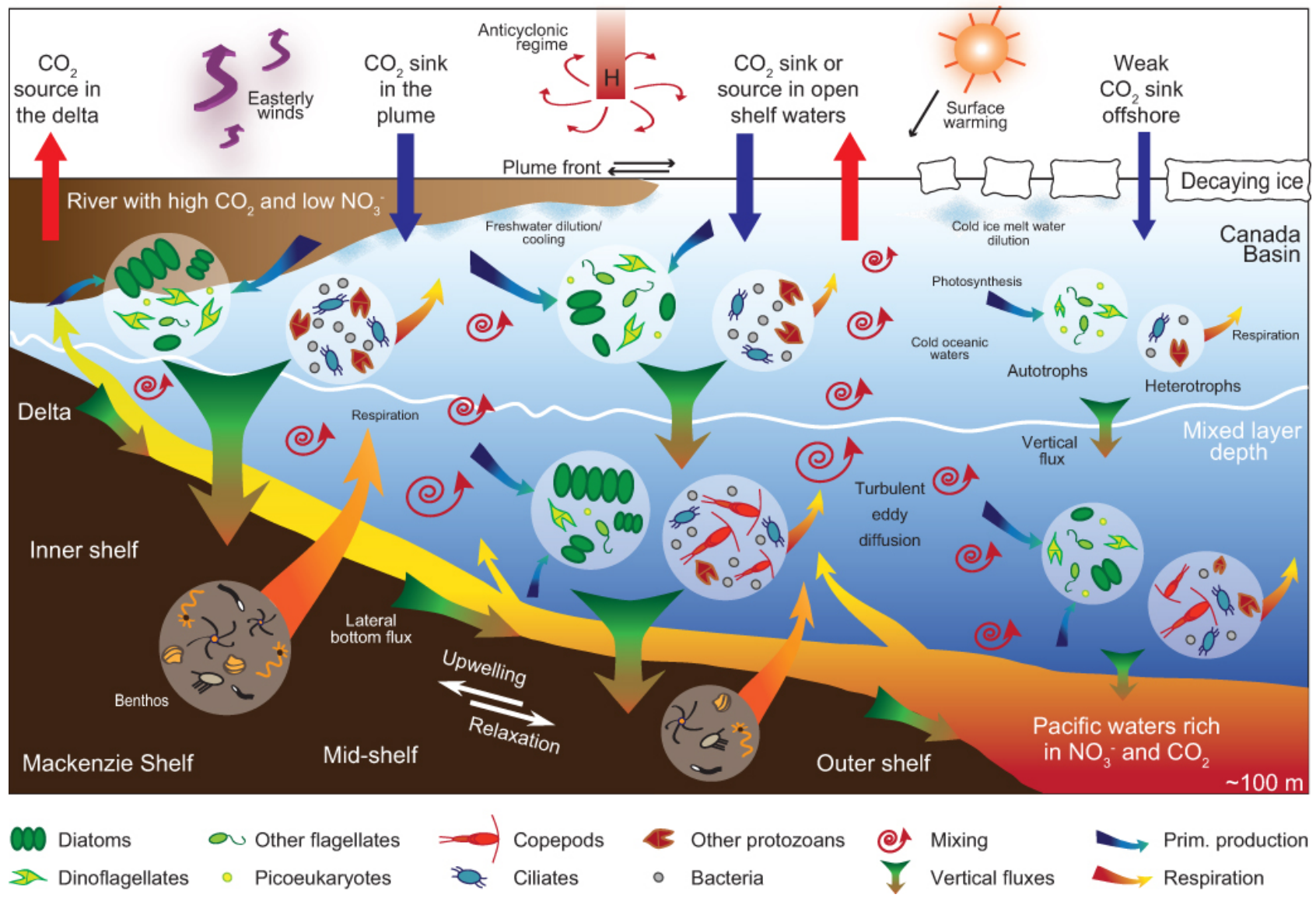

Figure 13. Schematics of food web structure and environmental forcings that synergistically drive ecosystem metabolic balance and sea-toair $\mathrm{CO}_{2}$ fluxes along the shelf-basin gradient in the changing Beaufort Sea. A succinct legend is presented below the schematics, but see Sect. 5 for detailed explanation.

as for example if large rapidly sinking diatoms dominated the phytoplankton assemblage. In the case where PP remains low, $\mathrm{CO}_{2}$ outgassing has the potential to be massive even if it is fed through turbulent eddy diffusion resulting from winddriven or tidal mixing from below and across the mixed layer (Fig. 13). Therefore, monitoring the upwelling flow along the Arctic margin (e.g., through moorings, remote-sensing) is a key issue if insightful time series of deep-water invasion over shallow shelf areas of biological importance are to be produced (cf. Pickart et al., 2013).

The balance between PP and heterotrophic respiration is a further process that will dictate if a given region might shift from a sink or a source of $\mathrm{CO}_{2}$ (Fig. 13). Over the Mackenzie Shelf, pelagic and benthic heterotrophic activity is typically linked to pulses in fresh food supply (Renaud et al., 2007; Forest et al., 2011) and more investigation is needed to conclude on the actual food web response to terrigenous carbon, which appears to have low bioavailability - at least in its dissolved phase (Shen et al., 2012). We cannot dismiss that bacteria and protozoans utilize allochthonous carbon to partly support their growth and metabolism, especially around the delta. But to which extent terrigenous carbon is incorporated and transferred into the Beaufort Sea food web is still an issue not fully resolved. Based on our analyses, the transfer of riverine carbon from microorganisms to higher trophic levels through calanoid copepods would be difficult given the spatial decoupling between mesozooplankton biomass and the routing of the river plume. Mesozooplankton were rather concentrated in the sub-surface layer, in association with a large biomass of diatoms nearby Cape Bathurst (as observed by Walkusz et al., 2012). The Mackenzie River indeed provided a substantial amount of nutrients that enhanced PP locally in the plume where the strongest $\mathrm{CO}_{2}$ sink was detected (Fig. 4f). This implies that riverine DOC is not fully respired and contrasts with the Mackenzie estuary just a few kilometers nearby, where high respiration, warm surface temperature, and potential nearshore upwelling contribute to make this area the strongest $\mathrm{CO}_{2}$ source (cf. Chen et al., 2012). With the collapse of permafrost and the projected increase in freshwater runoff, the Mackenzie River discharge and its 
organic components might be potentially very different, both qualitatively and quantitatively, in a few decades. This critical issue cannot be properly addressed without the implementation of a series of monitoring stations across the estuary and over the shelf that would help resolve the balance between PP and respiration and improve remote sensing estimates.

Concomitantly to the development of a more dynamic carbon cycling over the Mackenzie Shelf (see also Tremblay et al., 2011; Tolosa et al., 2013), the Canada Basin is accumulating freshwater from ice melt and riverine input, thus getting more stratified (Fichot et al., 2013; McLaughlin et al., 2013). As a result, the limited vertical exchange of nutrients and organic carbon between the surface and sub-surface layer in the Canada Basin is inducing a food web above the MLD exclusively based on recycling and single-celled organisms (Fig. 13). This region still acts as a weak sink for atmospheric $\mathrm{CO}_{2}$, essentially because of sea ice melt (cf. Else et al., 2013a). Below the surface, a diluted food web is present (see also Forest et al., 2012), which benefits from the weak local PP as well as from lateral inputs from the shelf (e.g., advection of eroded sediment, oblique flux of phyto-detritus). However, with the progressive deepening of the nutricline and chl $a$ maximum in the Canada Basin (Carmack and McLaughlin, 2011), lateral inputs from the shelf could become the dominant energy pathway for sustaining the pelagic food web in the deep Canada Basin (cf. Forest et al., 2012; Shah et al., 2013). This underscores that the crossshelf flux of organic matter over the slope and in the basin is also among the most important variables to monitor if the future Arctic marine carbon cycling and the implications for food web capacity and efficiency are to be accurately understood and modeled.

\section{The Supplement related to this article is available online at doi:10.5194/bg-11-2827-2014-supplement.}

Acknowledgements. This work was supported in the field by the officers and crew members of the CCGS Amundsen. We express gratitude to L. Prieur, M. Picheral and C. Marec for the deployment of the CTD/UVP-rosette and for the processing of UVP data. We thank P. Guillot for the validation of CTD data. We gratefully thank S. Lessard, M. Poulin and M. Gosselin for phytoplankton taxonomy data and for comments on the initial manuscript. Special thanks to L. Stemmann, A. Mucci, E. Ortega-Retuerta, F. Joux, W. Jeffrey, H. Link, P. Archambault, and G. Chaillou from the Malina team for sharing part of their data sets. Thanks to N. Garcia and J. Gagnon for the measurement of nutrients and primary production on the field. Special thanks M.-B. Gagné for the processing and extraction of satellite-derived PP rates. We thank M. Fortier, K. Lévesque and J. Ehn for the organization of the fieldwork, workshops and for support at sea. This study was conducted as part of the Malina Scientific Program funded by
ANR (Agence nationale de la recherche), INSU-CNRS (Institut national des sciences de l'univers - Centre national de la recherche scientifique), CNES (Centre national d'études spatiales) and ESA (European Space Agency). Additional support from ArcticNet (a Network of Centres of Excellence of Canada) was welcomed and appreciated. This work is a joint contribution to the Malina Project and to the research programs of Québec-Océan, ArcticNet, the Takuvik Joint U. Laval/CNRS Laboratory, the Arctic in Rapid Transition (ART) Initiative, to the Canada Research Chair on the Response of Marine Arctic Ecosystems to Climate Warming, and to the Canada Excellence Research Chair (CERC) in Remote Sensing of Canada's New Arctic Frontier.

Edited by: S. Belanger

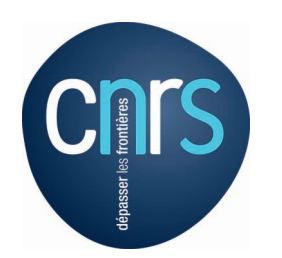

The publication of this article is financed by CNRS-INSU.

\section{References}

Anderson, L. G., Tanhua, T., Björk, G., Hjalmarsson, S., Jones, E., Jutterström, S., Rudels, B., Swift, J. H., and Wahlstöm, I.: Arctic ocean shelf-basin interaction: An active continental shelf $\mathrm{CO}_{2}$ pump and its impact on the degree of calcium carbonate solubility, Deep-Sea Res. Pt. I, 57, 869-879, doi:10.1016/j.dsr.2010.03.012, 2010.

Ardyna, M., Babin, M., Gosselin, M., Devred, E., Bélanger, S., Matsuoka, A., and Tremblay, J.: Parameterization of vertical chlorophyll a in the Arctic Ocean: impact of the subsurface chlorophyll maximum on regional, seasonal and annual primary production estimates, Biogeosciences, 10, 4383-4404, doi:10.5194/bg-104383-2013, 2013.

Barber, D. G., and Hanesiak, J. M.: Meteorological forcing of sea ice concentrations in the southern Beaufort Sea over the period 1979 to 2000, J. Geophys. Res.-Oceans, 109, C06014, doi:10.1029/2003jc002027, 2004.

Bates, N. R., Moran, S. B., Hansell, D. A., and Mathis, J. T.: An increasing $\mathrm{CO}_{2}$ sink in the Arctic Ocean due to sea-ice loss, Geophys. Res. Lett., 33, L23609, doi:10.1029/2006g1027028, 2006.

Bélanger, S., Babin, M., and Tremblay, J.-É.: Increasing cloudiness in Arctic damps the increase in phytoplankton primary production due to sea ice receding, Biogeosciences, 10, 4087-4101, doi:10.5194/bg-10-4087-2013, 2013.

Ben Mustapha, S. B., Bélanger, S., and Larouche, P.: Evaluation of ocean color algorithms in the southeastern Beaufort Sea, Canadian Arctic: New parameterization using SeaWiFS, MODIS, and MERIS spectral bands, Can. J. Remote Sens., 38, 535-556, doi:10.5589/m12-045, 2012.

Bérard-Therriault, L., Poulin, M., and Bossé, L.: Guide d'identification du phytoplancton marin de l'estuaire et du golfe du Saint-Laurent: incluant également certains protozaires, 128, NRC Research Press, 1999.

Bourgain, P., Gascard, J. C., Shi, J., and Zhao, J.: Large-scale temperature and salinity changes in the upper Canadian Basin of the 
Arctic Ocean at a time of a drastic Arctic Oscillation inversion, Ocean Sci., 9, 447-460, doi:10.5194/os-9-447-2013, 2013.

Brey, T.: Population dynamics in benthic invertebrates, A virtual handbook, Alfred Wegener Institute for Polar and Marine Research, Bremerhaven, Germany, http://hdl.handle.net/10013/ epic.15243, 2001.

Bussey, H. J.: Microzooplankton herbivory and bacterivory in the North Water Polynya, Thesis (M.Sc.)-Memorial University of Newfoundland, 2003, Biology, 2003.

Cai, W.-J., Chen, L., Chen, B., Gao, Z., Lee, S. H., Chen, J., Pierrot, D., Sullivan, K., Wang, Y., and Hu, X.: Decrease in the $\mathrm{CO}_{2}$ uptake capacity in an ice-free Arctic Ocean basin, Science, 329, 556-559, 2010.

Carmack, E. and Chapman, D. C.: Wind-driven shelf/basin exchange on an Arctic shelf: The joint roles of ice cover extent and shelf-break bathymetry, Geophys. Res. Lett., 30, 1778, doi:10.1029/2003GL017526, 2003.

Carmack, E. and McLaughlin, F.: Towards recognition of physical and geochemical change in Subarctic and Arctic Seas, Prog. Oceanogr., 90, 90-104, doi:10.1016/j.pocean.2011.02.007, 2011.

Carmack, E. C. and MacDonald, R. W.: Oceanography of the Canadian Shelf of the Beaufort Sea: a Setting for Marine Life, Arctic, 55, Supplement 1, 29-45, 2002.

Carmack, E. C., Macdonald, R. W., and Jasper, S.: Phytoplankton productivity on the Canadian Shelf of the Beaufort Sea, Mar. Ecol.-Prog. Ser., 277, 37-50, 2004.

Caron, D. A., Goldman, J. C., and Fenchel, T.: Protozoan respiration and metabolism, Ecology of marine protozoa, Oxford University Press, New York, 307-322, 1990.

Chen, C.-T. A., Huang, T.-H., Fu, Y.-H., Bai, Y., and He, X.: Strong sources of $\mathrm{CO}_{2}$ in upper estuaries become sinks of $\mathrm{CO}_{2}$ in large river plumes, Curr. Opin. Environ. Sust., 4, 179-185, doi:10.1016/j.cosust.2012.02.003, 2012.

Codispoti, L. A., Kelly, V., Thessen, A., Matrai, P., Suttles, S., Hill, V., Steele, M., and Light, B.: Synthesis of primary production in the Arctic Ocean: III. Nitrate and phosphate based estimates of net community production, Prog. Oceanogr., 110, 126-150, doi:10.1016/j.pocean.2012.11.006, 2013.

Collos, Y., and Slawyk, G.: $13 \mathrm{c}$ and $15 \mathrm{~N}$ uptake by marine phytoplankton. 111. Interactions in euphotic zone profiles of stratified oceanic areas, Mar. Ecol.-Prog. Ser, 19, 223-231, 1984.

Comeau, A. M., Li, W. K. W., Tremblay, J.-â., Carmack, E. C., and Lovejoy, C.: Arctic Ocean Microbial Community Structure before and after the 2007 Record Sea Ice Minimum, PLoS ONE, 6, e27492, doi:10.1371/journal.pone.0027492, 2011.

Connelly, T. L., Deibel, D., and Parrish, C. C.: Biogeochemistry of Near-Bottom Suspended Particulate Matter of the Beaufort Sea Shelf (Arctic Ocean): C, N, P, d13C and Fatty Acids, Cont. Shelf Res., 43, 120-132, doi:10.1016/j.csr.2012.05.011, 2012.

Crease, J.: The acquisition, calibration and analysis of CTD data. Unesco Technical Papers in Marine Science No. 54, (A Report of SCOR Working Group 51), Division of Marine Sciences, UNESCO, Paris, 105 pp., 1988.

D'Errico, J. R.: Understanding Gridfit, http://www.mathworks.com/ matlabcentral/fileexchange/8998-surface-fitting-using-gridfit, 2006.
Darnis, G. and Fortier, L.: Zooplankton respiration and the export of carbon at depth in the Amundsen Gulf (Arctic Ocean), J. Geophys. Res.-Oceans, 117, C04013, doi:10.1029/2011jc007374, 2012.

Denman, K., Christian, J. R., Steiner, N., Pörtner, H.-O., and Nojiri, Y.: Potential impacts of future ocean acidification on marine ecosystems and fisheries: current knowledge and recommendations for future research, ICES J. Mar. Sci., 68, 1019-1029, doi:10.1093/icesjms/fsr074, 2011.

Dickson, A. and Millero, F.: A comparison of the equilibrium constants for the dissociation of carbonic acid in seawater media, Deep-Sea Res. Pt. I, 34, 1733-1743, 1987.

Doxaran, D., Ehn, J., Bélanger, S., Matsuoka, A., Hooker, S., and Babin, M.: Optical characterisation of suspended particles in the Mackenzie River plume (Canadian Arctic Ocean) and implications for ocean colour remote sensing, Biogeosciences, 9, 32133229, doi:10.5194/bg-9-3213-2012, 2012.

Duarte, C. M. and Regaudie-de-Gioux, A.: Thresholds of gross primary production for the metabolic balance of marine planktonic communities, Limnol. Oceanogr, 54, 1015-1022, 2009.

Ducklow, H. W. and Doney, S. C.: What Is the Metabolic State of the Oligotrophic Ocean? A Debate, Annu. Rev. Mar. Sci., 5, 525533, doi:10.1146/annurev-marine-121211-172331, 2013.

Else, B. G. T., Papakyriakou, T. N., Galley, R. J., Mucci, A., Gosselin, M., Miller, L. A., Shadwick, E. H., and Thomas, H.: Annual cycles of $\mathrm{pCO}_{2} \mathrm{sw}$ in the southeastern Beaufort Sea: New understandings of air-sea $\mathrm{CO}_{2}$ exchange in arctic polynya regions, J. Geophys. Res.-Oceans, 117, C00G13, doi:10.1029/2011jc007346, 2012.

Else, B. G. T., Galley, R. J., Lansard, B., Barber, D. G., Brown, K., Miller, L. A., Mucci, A., Papakyriakou, T. N., Tremblay, J. É., and Rysgaard, S.: Further observations of a decreasing atmospheric $\mathrm{CO}_{2}$ uptake capacity in the Canada Basin (Arctic Ocean) due to sea ice loss, Geophys. Res. Lett., 40, 1132-1137, doi:10.1002/grl.50268, 2013a.

Else, B. G. T., Papakyriakou, T. N., Asplin, M. G., Barber, D. G., Galley, R. J., Miller, L. A., and Mucci, A.: Annual cycle of airsea $\mathrm{CO}_{2}$ exchange in an Arctic Polynya Region, Global Biogeochem. Cy., 27, 388-398, doi:10.1002/gbc.20016, 2013b.

Fenchel, T.: Respiration in aquatic protists, Respiration in Aquatic Ecosystems, 47-56, 2005.

Fichot, C. G., Kaiser, K., Hooker, S. B., Amon, R. M., Babin, M., Bélanger, S., Walker, S. A., and Benner, R.: Pan-Arctic distributions of continental runoff in the Arctic Ocean, Scientific reports, 3, doi:10.1038/srep01053, 2013.

Forest, A., Sampei, M., Hattori, H., Makabe, R., Sasaki, H., Fukuchi, M., Wassmann, P., and Fortier, L.: Particulate organic carbon fluxes on the slope of the Mackenzie Shelf (Beaufort Sea): Physical and biological forcing of shelf-basin exchanges, J. Mar. Syst., 68, 39-54, doi:10.1016/j.jmarsys.2006.10.008, 2007.

Forest, A., Tremblay, J.-R., Gratton, Y., Martin, J., Gagnon, J., Darnis, G., Sampei, M., Fortier, L., Ardyna, M., Gosselin, M., Hattori, H., Nguyen, D., Maranger, R., Vaque, D., Marrase, C., Pedros-Aliio, C., Sallon, A., Michel, C., Kellogg, C., Deming, J., Shadwick, E., Thomas, H., Link, H., Archambault, P., and Piepenburg, D.: Biogenic carbon flows through the planktonic food web of the Amundsen Gulf (Arctic Ocean): A synthesis of field measurements and 
inverse modeling analyses, Prog. Oceanogr., 91, 410-436, doi:10.1016/j.pocean.2011.05.002, 2011.

Forest, A., Stemmann, L., Picheral, M., Burdorf, L., Robert, D., Fortier, L., and Babin, M.: Size distribution of particles and zooplankton across the shelf-basin system in Southeast Beaufort Sea: combined results from an Underwater Vision Profiler and vertical net tows, Biogeosciences, 9, 1301-1320, doi:10.5194/bg-9-1301-2012, 2012.

Forest, A., Babin, M., Stemmann, L., Picheral, M., Sampei, M., Fortier, L., Gratton, Y., Bélanger, S., Devred, E., Sahlin, J., Doxaran, D., Joux, F., Ortega-Retuerta, E., Martìn, J., Jeffrey, W. H., Gasser, B., and Carlos Miquel, J.: Ecosystem function and particle flux dynamics across the Mackenzie Shelf (Beaufort Sea, Arctic Ocean): an integrative analysis of spatial variability and biophysical forcings, Biogeosciences, 10, 2833-2866, doi:10.5194/bg-10-2833-2013, 2013.

Francis, J. A. and Vavrus, S. J.: Evidence linking Arctic amplification to extreme weather in mid-latitudes, Geophys. Res. Lett., 39, L06801, 10.1029/2012g1051000, 2012.

Galley, R. J., Else, B., Prinsenberg, S., Babb, D., and Barber, D.: Summer Sea Ice Concentration, Motion, and Thickness Near Areas of Proposed Offshore Oil and Gas Development in the Canadian Beaufort Sea-2009, Arctic, 66, 105-116, 2013.

Garneau, M.-E., Vincent, W. F., Alonso-Saez, L., Gratton, Y., and Lovejoy, C.: Prokaryotic community structure and heterotrophic production in a river-influenced coastal arctic ecosystem, Aquat. Microb. Ecol., 42, 27-40, 2006.

Garneau, M. E., Roy, S., Pedrós-Alió, C., Lovejoy, C., Gratton, Y., and Vincent, W. F.: Seasonal dynamics of bacterial biomass and production in a coastal arctic ecosystem: Franklin Bay, western Canadian Arctic, J. Geophys. Res.-Oceans, 113, C07S91, doi:10.1029/2007JC004281, 2008.

Goñi, M. A., Yunker, M. B., MacDonald, R. W., and Eglinton, T. I.: Distribution and sources of organic biomarkers in Arctic sediments from the Mackenzie River and Beaufort Shelf, Mar. Chem. 71, 23-51, 2000.

Gordeev, V. V.: Fluvial sediment flux to the Arctic Ocean, Geomorphology, 80, 94-104, doi:10.1016/j.geomorph.2005.09.008, 2006.

Grant, A. L. M., and Belcher, S. E.: Wind-Driven Mixing below the Oceanic Mixed-layer, J. Phys. Oceanogr., 41, 1556-1575, doi:10.1175/jpo-d-10-05020.1, 2011.

Guidi, L., Jackson, G. A., Stemmann, L., Miquel, J. C., Picheral, M., and Gorsky, G.: Relationship between particle size distribution and flux in the mesopelagic zone, Deep-Sea Res. Pt. I, 55, 1364 1374, doi:10.1016/j.dsr.2008.05.014, 2008.

Haas, C., Hendricks, S., Eicken, H., and Herber, A.: Synoptic airborne thickness surveys reveal state of Arctic sea ice cover, Geophys. Res. Lett., 37, L09501, doi:10.1029/2010g1042652, 2010.

Holmes, R. M., Aminot, A., Kérouel, R., Hooker, B. A., and Peterson, B. J.: A simple and precise method for measuring ammonium in marine and freshwater ecosystems, Can. J. Fish. Aquat. Sci., 56, 1801-1808, doi:10.1139/f99-128, 1999.

Holte, J., and Talley, L.: A New Algorithm for Finding Mixedlayer Depths with Applications to Argo Data and Subantarctic Mode Water Formation, J. Atmos. Ocean. Tech., 26, 1920-1939, doi:10.1175/2009JTECHO543.1, 2009.

Janout, M. A., Hölemann, J., and Krumpen, T.: Cross-shelf transport of warm and saline water in response to sea ice drift on the Laptev Sea shelf, J. Geophys. Res.-Oceans, 118, 563-576, doi:10.1029/2011jc007731, 2013.

Kaleschke, L., Lüpkes, C., Vihma, T., Haarpaintner, J., Bochert, A., Hartmann, J., and Heygster, G.: SSM/I sea ice remote sensing for mesoscale oceanATMosphere interaction analysis Can. J. Remote Sens., 27, 526-537, 2001.

Keeling, C., Piper, S., Bacastow, R., Wahlen, M., Whorf, T., Heimann, M., and Meijer, H.: Atmospheric $\mathrm{CO}_{2}$ and ${ }^{13} \mathrm{CO}_{2} \mathrm{Ex}-$ change with the Terrestrial Biosphere and Oceans from 1978 to 2000: Observations and Carbon Cycle Implications, in: A History of Atmospheric $\mathrm{CO}_{2}$ and Its Effects on Plants, Animals, and Ecosystems, edited by: Baldwin, I. T., Caldwell, M. M., Heldmaier, G., Jackson, R., Lange, O. L., Mooney, H. A., Schulze, E. D., Sommer, U., Ehleringer, J., Denise Dearing, M., and Cerling, T., Ecological Studies, Springer New York, 83-113, 2005.

Kirchman, D.: Leucine incorporation as a measure of biomass production by heterotrophic bacteria, Handbook of methods in aquatic microbial ecology. Lewis, 509-512, 1993.

Kirchman, D. L., Hill, V., Cottrell, M. T., Gradinger, R., Malmstrom, R. R., and Parker, A.: Standing stocks, production, and respiration of phytoplankton and heterotrophic bacteria in the western Arctic Ocean, Deep-Sea Res. Pt. II, 56, 1237-1248, doi:10.1016/j.dsr2.2008.10.018, 2009.

Kobari, T., Kitamura, M., Minowa, M., Isami, H., Akamatsu, H., Kawakami, H., Matsumoto, K., Wakita, M., and Honda, M. C.: Impacts of the wintertime mesozooplankton community to downward carbon flux in the subarctic and subtropical Pacific Oceans, Deep-Sea Res. Pt. II, 81, 78-88, doi:10.1016/j.dsr.2013.07.003, 2013.

Kulikov, E. A., Rabinovich, A. B., and Carmack, E. C.: Barotropic and baroclinic tidal currents on the Mackenzie shelf break in the southeastern Beaufort Sea, J. Geophys. Res.-Oceans, 109, C05020, doi:10.1029/2003jc001986, 2004.

Langdon, C.: On the causes of interspecific differences in the growth-irradiance relationship for phytoplankton. II. A general review, J. Plankton Res., 10, 1291-1312, 1988.

Lansard, B., Mucci, A., Miller, L. A., Macdonald, R. W., and Gratton, Y.: Seasonal variability of water mass distribution in the southeastern Beaufort Sea determined by total alkalinity and $\delta^{18} \mathrm{O}$, J. Geophys. Res.-Oceans, 117, C03003, doi:10.1029/2011JC00729, 2012.

Le Fouest, V., Babin, M., and Tremblay, J.-É.: The fate of riverine nutrients on Arctic shelves, Biogeosciences, 10, 3661-3677, doi:10.5194/bg-10-3661-2013, 2013.

Legendre, L. and Niquil, N.: Large-scale regional comparisons of ecosystem processes: Methods and approaches, J. Mar. Syst., 109, 4-21, doi:10.1016/j.jmarsys.2011.11.021, 2013.

Leitch, D. R., Carrie, J., Lean, D., Macdonald, R. W., Stern, G. A., and Wang, F.: The delivery of mercury to the Beaufort Sea of the Arctic Ocean by the Mackenzie River, Sci. Total Environ., 373, 178-195, doi:10.1016/j.scitotenv.2006.10.041, 2007.

Lewis, E. and Wallace, D. W. R.: CO2SYS-Program developed for the $\mathrm{CO} 2$ system calculations, Carbon Dioxide Inf. Anal. Center, Report ORNL/CDIAC-105, Oak Ridge, Tenn., USA, 1998.

Li, W. K. W., McLaughlin, F. A., Lovejoy, C., and Carmack, E. C.: Smallest algae thrive as the Arctic Ocean freshens, Science, 326, 539, doi:10.1126/science.1179798, 2009.

Link, H., Chaillou, G., Forest, A., Piepenburg, D., and Archambault, P.: Multivariate benthic ecosystem functioning in the Arc- 
tic - benthic fluxes explained by environmental parameters in the southeastern Beaufort Sea, Biogeosciences, 10, 5911-5929, doi:10.5194/bg-10-5911-2013, 2013.

Lund, H., Vatter, A., and Hanson, J.: Biochemical and cytological changes accompanying growth and differentiation in the roots of Zea mays, The Journal of biophysical and biochemical cytology, 4, 87-98, 1958.

Macdonald, R. and Yu, Y.: The Mackenzie Estuary of the Arctic Ocean, in: The Handbook of Environmental Chemistry, edited by: Wangersky, P. J., Springer, Berlin, 91-120, 2006.

Macdonald, R. W., Solomon, S. M., Cranston, R. E., Welch, H. E., Yunker, M. B., and Gobeil, C.: A sediment and organic carbon budget for the Canadian Beaufort Shelf, Mar. Geol., 144, 255273, 1998.

Magen, C., Chaillou, G., Crowe, S. A., Mucci, A., Sundby, B., Gao, A., Makabe, R., and Sasaki, H.: Origin and fate of particulate organic matter in the southern Beaufort Sea - Amundsen Gulf region, Canadian Arctic, Estuar. Coastal Shelf Sci., 86, 31-41, doi:10.1016/j.ecss.2009.09.009, 2010.

Martin, J., Tremblay, J. E., Gagnon, J., Tremblay, G., Lapoussière, A., Jose, C., Poulin, M., Gosselin, M., Gratton, Y., and Michel, C.: Prevalence, structure and properties of subsurface chlorophyll maxima in Canadian Arctic waters, Mar. Ecol.-Prog. Ser., 42, 69-84, doi:10.3354/meps08666, 2010.

Maslanik, J. and Stroeve, J. C.: Near-real-time DMSP SSM/I daily polar gridded sea ice concentrations, (January-December 2009), Boulder, Colorado USA: National Snow and Ice Data Center, http://nsidc.org/data/nsidc-0081.html, 1999.

Mathis, J. T., Pickart, R. S., Byrne, R. H., McNeil, C. L., Moore, G. W. K., Juranek, L. W., Liu, X., Ma, J., Easley, R. A., Elliot, M. M., Cross, J. N., Reisdorph, S. C., Bahr, F., Morison, J., Lichendorf, T., and Feely, R. A.: Storm-induced upwelling of high $p \mathrm{CO}_{2}$ waters onto the continental shelf of the western Arctic Ocean and implications for carbonate mineral saturation states, Geophys. Res. Lett., 39, L07606, doi:10.1029/2012gl051574, 2012.

Matsuoka, A., Bricaud, A., Benner, R., Para, J., Sempéré, R., Prieur, L., Bélanger, S., and Babin, M.: Tracing the transport of colored dissolved organic matter in water masses of the Southern Beaufort Sea: relationship with hydrographic characteristics, Biogeosciences, 9, 925-940, doi:10.5194/bg-9-925-2012, 2012.

Matsuoka, A., Hooker, S. B., Bricaud, A., Gentili, B., and Babin, M.: Estimating absorption coefficients of colored dissolved organic matter (CDOM) using a semi-analytical algorithm for southern Beaufort Sea waters: application to deriving concentrations of dissolved organic carbon from space, Biogeosciences, 10, 917-927, doi:10.5194/bg-10-917-2013, 2013.

McLaughlin, F. A., Carmack, E., Proshutinsky, A., Krishfield, R. A., Guay, C. K., Yamamoto-Kawai, M., Jackson, J. M., and Williams, W. J.: The rapid response of the Canada Basin to climate forcing: From bellwether to alarm bells, Oceanography, 24, 146-159, doi:10.5670/oceanog.2011.66, 2011.

McPhee, M. G.: Intensification of Geostrophic Currents in the Canada Basin, Arctic Ocean, J. Climate, 26, 3130-3138, 10.1175/jcli-d-12-00289.1, 2013.

Mehrbach, C.: Measurement of the apparent dissociation constants of carbonic acid in seawater at atmospheric pressure, http://hdl. handle.net/1957/28375, 1973.
Menden-Deuer, S. and Lessard, E. J.: Carbon to volume relationships for dinoflagellates, diatoms, and other protist plankton, Limnol. Oceanogr., 45, 569-579, 2000.

Moore, G. W. K.: Decadal variability and a recent amplification of the summer Beaufort Sea High, Geophys. Res. Lett., 39, L10807, doi:10.1029/2012g1051570, 2012.

Morata, N., Renaud, P. E., Brugel, S., Hobson, K. A., and Johnson, B. J.: Spatial and seasonal variations in the pelagic-benthic coupling of the southeastern Beaufort Sea revealed by sedimentary biomarkers, Mar. Ecol.-Prog. Ser., 371, 47-63, 2008.

Morison, J., Kwok, R., Peralta-Ferriz, C., Alkire, M., Rigor, I., Andersen, R., and Steele, M.: Changing Arctic Ocean freshwater pathways, Nature, 481, 66-70, 2012.

Mucci, A., Lansard, B., Miller, L. A., and Papakyriakou, T. N.: $\mathrm{CO}_{2}$ fluxes across the air-sea interface in the southeastern Beaufort Sea: Ice-free period, J. Geophys. Res.-Oceans, 115, C04003, doi:10.1029/2009jc005330, 2010.

Nguyen, D., Maranger, R., Tremblay, J.-É., and Gosselin, M.: Respiration and bacterial carbon dynamics in the Amundsen Gulf, western Canadian Arctic, J. Geophys. Res.-Oceans, 117, C00G16, doi:10.1029/2011jc007343, 2012.

NSIDC: National Snow and Ice Data Center, Arctic Sea Ice News and Analysis, 9 September 2009, http://nsidc.org/arcticseaicenews/2009/09/ winds-cause-sea-ice-to-spread-in-august/, 2009.

O’Brien, M. C., Macdonald, R. W., Melling, H., and Iseki, K.: Particle fluxes and geochemistry on the Canadian Beaufort Shelf: Implications for sediment transport and deposition, Cont. Shelf Res., 26, 41-81, 2006.

O’Brien, M. C., Melling, H., Pedersen, T. F., and Macdonald, R. W.: The role of eddies and energetic ocean phenomena in the transport of sediment from shelf to basin in the Arctic, J. Geophys. Res.-Oceans, 116, C08001, doi:10.1029/2010jc006890, 2011.

Ogi, M. and Rigor, I. G.: Trends in Arctic sea ice and the role of atmospheric circulation, Atmos. Sci. Lett., 14, 97-101, doi:10.1002/asl2.423, 2013.

Olenina, I.: Biovolumes and size-classes of phytoplankton in the Baltic Sea, http://epic.awi.de/30141/1/bsep106.pdf, 2006.

Ortega-Retuerta, E., Jeffrey, W. H., Babin, M., Bélanger, S., Benner, R., Marie, D., Raimbault, P., and Joux, F.: Carbon fluxes in the Canadian Arctic: patterns and drivers of bacterial abundance, production and respiration on the Beaufort Sea Margin, Biogeosciences, 9, 3679-3692, doi:10.5194/bg-9-3679-2012, 2012.

Overland, J. E.: Meteorology of the Beaufort Sea, J. Geophys. Res.Oceans, 114, C00A07, doi:10.1029/2008jc004861, 2009.

Overland, J. E., Francis, J. A., Hanna, E., and Wang, M.: The recent shift in early summer Arctic atmospheric circulation, Geophys. Res. Lett., 39, L19804, doi:10.1029/2012g1053268, 2012.

Parkinson, C. L. and Comiso, J. C.: On the 2012 record low Arctic sea ice cover: Combined impact of preconditioning and an August storm, Geophys. Res. Lett., 40, 1356-1361, doi:10.1002/grl.50349, 2013.

Parsons, T. R., Webb, D. G., Rokeby, B. E., Lawrence, M., Hopky, G. E., and Chiperzak, D. B.: Autotrophic and heterotrophic production in the Mackenzie river/Beaufort Sea estuary, Polar Biol., 9, 261-266, doi:10.1007/bf00263774, 1989.

Peltzer, E. T.: http://www.mbari.org/staff/etp3/regress/lsqbisec.m, 2008. 
Picheral, M., Guidi, L., Stemmann, L., Karl, D. M., Iddaoud, G., and Gorsky, G.: The Underwater Vision Profiler 5: An advanced instrument for high spatial resolution studies of particle size spectra and zooplankton, Limnol. Oceanogr. Meth., 8, 462-473, 2010.

Pickart, R. S., Schulze, L. M., Moore, G. W. K., Charette, M. A., Arrigo, K. R., van Dijken, G., and Danielson, S. L.: Longterm trends of upwelling and impacts on primary productivity in the Alaskan Beaufort Sea, Deep-Sea Res. Pt. I, 79, 106-121, doi:10.1016/j.dsr.2013.05.003, 2013.

Pierrot, D., Neill, C., Sullivan, K., Castle, R., Wanninkhof, R., Luger, H., Johannessen, T., Olsen, A., Feely, R. A., and Cosca, C. E.: Recommendations for autonomous underway $p \mathrm{CO}_{2}$ measuring systems and data-reduction routines, Deep-Sea Res. Pt. II, 56, 512-522, doi:10.1016/j.dsr2.2008.12.005, 2009.

Pineault, S., Tremblay, J.-É., Gosselin, M., Thomas, H., and Shadwick, E.: The isotopic signature of particulate organic $\mathrm{C}$ and $\mathrm{N}$ in bottom ice: Key influencing factors and applications for tracing the fate of ice-algae in the Arctic Ocean, J. Geophys. Res.Oceans, 118, 287-300, doi:10.1029/2012jc008331, 2013.

Raimbault, P. and Garcia, N.: Evidence for efficient regenerated production and dinitrogen fixation in nitrogen-deficient waters of the South Pacific Ocean: impact on new and export production estimates, Biogeosciences, 5, 323-338, 10, http://www.biogeosciences.net/5/323/10/.5194/bg-5-323-2008, 2008.

Raimbault, P., Slawyk, G., Coste, B., and Fry, J.: Feasibility of using an automated colorimetric procedure for the determination of seawater nitrate in the 0 to $100 \mathrm{nM}$ range: Examples from field and culture, Mar. Biol., 104, 347-351, 1990.

Raimbault, P., Diaz, F., Pouvesle, W., and Boudjellal, B.: Simultaneous determination of particulate organic carbon, nitrogen and phosphorus collected on filters, using a semi-automatic wetoxidation method, Mar. Ecol.-Prog. Ser., 180, 289-295, 1999a.

Raimbault, P., Pouvesle, W., Diaz, F., Garcia, N., and Sempéré, R.: Wet-oxidation and automated colorimetry for simultaneous determination of organic carbon, nitrogen and phosphorus dissolved in seawater, Mar. Chem., 66, 161-169, 1999b.

Renaud, P. E., Morata, N., Ambrose, W. G., Bowie, J. J., and Chiuchiolo, A.: Carbon cycling by seafloor communities on the eastern Beaufort Sea shelf, J. Exp. Mar. Biol. Ecol., 349, 248-260, doi:10.1016/j.jembe.2007.05.021, 2007.

Robert, D., Falardeau-Côté, M., Suzuki, K., and Fortier, L.: Investigating trophic interactions between laraval Arctic cod (Boreogadus saida) and their zooplankton prey in the rapidly-warming Beaufort Sea, Proceedings of the 35th Annual Larval Fish Conference, 22-26 May 2011, Wilmington, NC, USA, 2011.

Sakshaug, E.: Primary and Secondary Production in the Arctic Seas, in: The Organic Carbon Cycle in the Arctic Ocean, edited by: Stein, R. and MacDonald, R. W., Springer-Verlag, New York, 57-81, 2004.

Sallon, A., Michel, C., and Gosselin, M.: Summertime primary production and carbon export in the coastal Arctic Ocean during the low ice year of 2008, Polar Biol., 34, 1989-2005, doi:10.1007/s00300-011-1055-5, 2011.

Sampei, M., Sasaki, H., Makabe, R., Forest, A., Hattori, H., Tremblay, J.-É., Gratton, Y., Fukuchi, M., and Fortier, L.: Production and retention of biogenic matter in the southeast Beaufort Sea during 2003-2004: insights from annual vertical particle fluxes of organic carbon and biogenic silica, Polar Biol., 34, 501-511, doi:10.1007/s00300-010-0904-y, 2011.

Sanders, R. W. and Gast, R. J.: Bacterivory by phototrophic picoplankton and nanoplankton in Arctic waters, FEMS Microbiology Ecology, 82, 242-253, doi:10.1111/j.15746941.2011.01253.x, 2012.

Shadwick, E. H., Thomas, H., Chierici, M., Else, B., Fransson, A., Michel, C., Miller, L. A., Mucci, A., Niemi, A., Papakyriakou, T., and Tremblay, J.-É.: Seasonal variability of the inorganic carbon system in the Amundsen Gulf region of the southeastern Beaufort Sea, Limnol. Oceanogr., 56, 303-322, doi:10.4319/lo.2011.56.1.0303, 2011.

Shah, S. R., Griffith, D. R., Galy, V., McNichol, A. P., and Eglinton, T. I.: Prominent bacterial heterotrophy and sources of ${ }^{13} \mathrm{C}$ depleted fatty acids to the interior Canada Basin, Biogeosciences Discuss., 10, 6695-6736, doi:10.5194/bgd-10-6695-2013, 2013.

Shen, Y., Fichot, C. G., and Benner, R.: Dissolved organic matter composition and bioavailability reflect ecosystem productivity in the Western Arctic Ocean, Biogeosciences, 9, 4993-5005, doi:10.5194/bg-9-4993-2012, 2012.

Simmonds, I. and Keay, K.: Extraordinary September Arctic sea ice reductions and their relationships with storm behavior over 1979-2008, Geophys. Res. Lett., 36, L19715, doi:10.1029/2009g1039810, 2009.

Simmonds, I. and Rudeva, I.: The great Arctic cyclone of August 2012, Geophys. Res. Lett., 39, L23709, doi:10.1029/2012g1054259, 2012.

Smith, D. C. and Azam, F.: A simple, economical method for measuring bacterial protein synthesis rates in seawater using $3 \mathrm{H}-$ leucine, Mar. Microb. Food Webs, 6, 107-114, 1992.

Sprent, P. and Dolby, G. R.: Query: the geometric mean functional relationship, Biometrics, 36, 547-550, 1980.

Sweeney, C., Gloor, E., Jacobson, A. R., Key, R. M., McKinley, G., Sarmiento, J. L., and Wanninkhof, R.: Constraining global air-sea gas exchange for $\mathrm{CO}_{2}$ with recent bomb ${ }^{14} \mathrm{C}$ measurements, Global Biogeochem. Cy., 21, GB2015, doi:10.1029/2006gb002784, 2007.

Timmermans, M. L., Proshutinsky, A., Krishfield, R. A., Perovich, D. K., Richter-Menge, J. A., Stanton, T. P., and Toole, J. M.: Surface freshening in the Arctic Ocean's Eurasian Basin: An apparent consequence of recent change in the winddriven circulation, J. Geophys. Res.-Oceans, 116, C00D03, doi:10.1029/2011jc006975, 2011.

Tolosa, I., Fiorini, S., Gasser, B., Martìn, J., and Miquel, J. C.: Carbon sources in suspended particles and surface sediments from the Beaufort Sea revealed by molecular lipid biomarkers and compound-specific isotope analysis, Biogeosciences, 10, 20612087, doi:10.5194/bg-10-2061-2013, 2013.

Tréguer, P. and Le Corre, P.: Manuel d'analyse des sels nutrifs dans l'eau de mer: utilisation de l'Autoanalyzer II Technicon (R), Université de Bretagne Occidentale, 1975.

Tremblay, J.-É., Michel, C., Hobson, K. A., Gosselin, M., and Price, N. M.: Bloom dynamics in early opening waters of the Arctic Ocean, Limnol. Oceanogr., 51, 900-912, 2006.

Tremblay, J.-É., Simpson, K., Martin, J., Miller, L. A., Gratton, Y., and Price, N. M.: Vertical stability and the annual dynamics of nutrients and chlorophyll fluorescence in the coastal, southeast Beaufort Sea, J. Geophys. Res.-Oceans, 113, C07S90, doi:10.1029/2007JC004547, 2008. 
Tremblay, J.-É., Bélanger, S., Barber, D. G., Asplin, M., Martin, J., Fortier, L., Darnis, G., Gratton, Y., Link, H., Archambault, P., Williams, W. G., Philippe, B., and Gosselin, M.: Climate forcing multiplies biological productivity in the Arctic Ocean, Geophys. Res. Lett., 38, L18604, doi:10.1029/2011GL048825, 2011.

Tremblay, J.-É., Raimbault, P., Garcia, N., Lansard, B., and Gagnon, J.: Impact of river discharge, upwelling and vertical mixing on nutrient loading and productivity of the Mackenzie Shelf, Biogeosciences Discuss., 10, 16675-16712, doi:10.5194/bgd-1016675-2013, 2013.

Vallières, C., Retamal, L., Ramlal, P., Osburn, C. L., and Vincent, W. F.: Bacterial production and microbial food web structure in a large arctic river and the coastal Arctic Ocean, J. Mar. Syst., 74, 756-773, doi:10.1016/j.jmarsys.2007.12.002, 2008.

Vaqué, D., Guadayol, Ò., Peters, F., Felipe, J., Angel-Ripoll, L., Terrado, R., Lovejoy, C., and Pedrós-Alió, C.: Seasonal changes in planktonic bacterivory rates under the ice-covered coastal Arctic Ocean, Limnol. Oceanogr., 53, 2427-2438, doi:10.4319/lo.2008.53.6.2427, 2008.

Vermaire, J. C., Pisaric, M. F. J., Thienpont, J. R., Courtney Mustaphi, C. J., Kokelj, S. V., and Smol, J. P.: Arctic climate warming and sea ice declines lead to increased storm surge activity, Geophys. Res. Lett., 40, 1386-1390, doi:10.1002/grl.50191, 2013.
Vonk, J. E., Mann, P. J., Davydov, S., Davydova, A., Spencer, R. G. M., Schade, J., Sobczak, W. V., Zimov, N., Zimov, S., Bulygina, E., Eglinton, T. I., and Holmes, R. M.: High biolability of ancient permafrost carbon upon thaw, Geophys. Res. Lett., 40, 2689 2693, doi:10.1002/grl.50348, 2013.

Weiss, R. and Price, B.: Nitrous oxide solubility in water and seawater, Mar. Chem., 8, 347-359, 1980.

Weiss, R. F.: Carbon dioxide in water and seawater: the solubility of a non-ideal gas, Mar. Chem., 2, 203-215, 1974.

Williams, W. J. and Carmack, E. C.: Combined effect of wind-forcing and isobath divergence on upwelling at Cape Bathurst, Beaufort Sea, J. Mar. Res., 66, 645-663, doi:10.1357/002224008787536808, 2008.

Williams, W. J., Carmack, E. C., Shimada, K., Melling, H., Aagaard, K., Macdonald, R. W., and Grant Ingram, R.: Joint effects of wind and ice motion in forcing upwelling in Mackenzie Trough, Beaufort Sea, Cont. Shelf Res., 26, 2352-2366, doi:10.1016/j.csr.2006.06.012, 2006.

Yamamoto-Kawai, M., McLaughlin, F. A., Carmack, E. C., Nishino, S., and Shimada, K.: Aragonite Undersaturation in the Arctic Ocean: Effects of Ocean Acidification and Sea Ice Melt, Science, 326, 1098-1100, doi:10.1126/science.1174190, 2009.

Zhang, J., Lindsay, R., Schweiger, A., and Steele, M.: The impact of an intense summer cyclone on 2012 Arctic sea ice retreat, Geophys. Res. Lett., 40, 720-726, doi:10.1002/grl.50190, 2013. 


\section{Appendix A: Uncertainty on $\mathrm{CO}_{2}$ fluxes and net community production estimates}

In this section we present an overview of the uncertainties related to $\mathrm{CO}_{2}$ fluxes and NCP estimates upon which our assessment of the functioning of the marine ecosystem during Malina is based. Mucci et al. (2010) and Else et al. (2013b) reviewed the uncertainties related to $\mathrm{CO}_{2}$ flux calculations in seasonally ice-covered Arctic waters. They underscored that the relationship between the gas transfer velocity parameter $(k)$ and the wind speed at $10 \mathrm{~m}(U)$ is still the largest source of error in flux calculations, although the difference between the most used relationships is about $15 \%$ (Mucci et al., 2010). Uncertainties related to $k-U$ relationships are also greatest during high wind speed conditions (e.g., $>30 \mathrm{~km} \mathrm{~h}^{-1}$ ) - a setting that was actually not observed during Malina 2009. However, the application of bulk formulae developed for open seas (like the one utilized here) have not been thoroughly evaluated for marginal ice zones. These equations represent a large potential of error even if they have been widely used within previous Arctic Ocean studies (e.g., Bates and Mathis, 2009; Else et al., 2013b and references therein). Based on our estimations of errors associated with (1) the differences between the partial pressure of $\mathrm{CO}_{2}$ in the atmosphere and in the ocean surface layer, (2) the gas exchange-wind speed relationship of Sweeney et al. (2007), and (3) the error associated to wind data, we could derive an overall uncertainty in our $\mathrm{CO}_{2}$ flux calculations that was estimated at $\pm 30 \%$. This error propagation estimate is within the envelope of uncertainties for $\mathrm{CO}_{2}$ fluxes obtained within previous studies in the area during summer months (i.e., $\pm 25 \%$ in Mucci et al., 2010; $\pm 20 \%$ in Shadwick et al., 2011; and $\pm 35 \%$ in Else et al., 2013b).

Computations of the uncertainty related to our NCP estimate is expected to be larger than that of $\mathrm{CO}_{2}$ fluxes given the numerous relationships employed to construct NCP estimates (see Sects. 2.5 to 2.7). Error on GPP estimates was derived from the unexplained variance between results from the on-deck experiments and in situ sample incubations enriched with ${ }^{15} \mathrm{~N}-\mathrm{N}_{2}$ (conducted at 5 stations, $n=43$ ). These in situ incubations were used as an independent control for the stimulation of PP by ${ }^{15} \mathrm{~N}$-tracer additions in nutrient-limited waters (Raimbault et al., 2008). The regression coefficient between the two data sets was 1.02 and the associated unexplained variance (error) was $25.3 \%$. Determining the uncertainty related to community respiration was a key challenge given the distinct conversion factors, metabolic relationships and plankton biomass estimates used to derive respiration. Using the 0.95 confidence interval associated with the various empirical equations binding biomass or production to respiration, and accounting for deviation in field measurement replicates, we could obtain a cumulated error of $\pm 50 \%$ for community respiration. The overall uncertainty on NCP estimates in our study is thus of $\pm 75 \%$. This value is quite high but is representative of our multi-methodological ap-
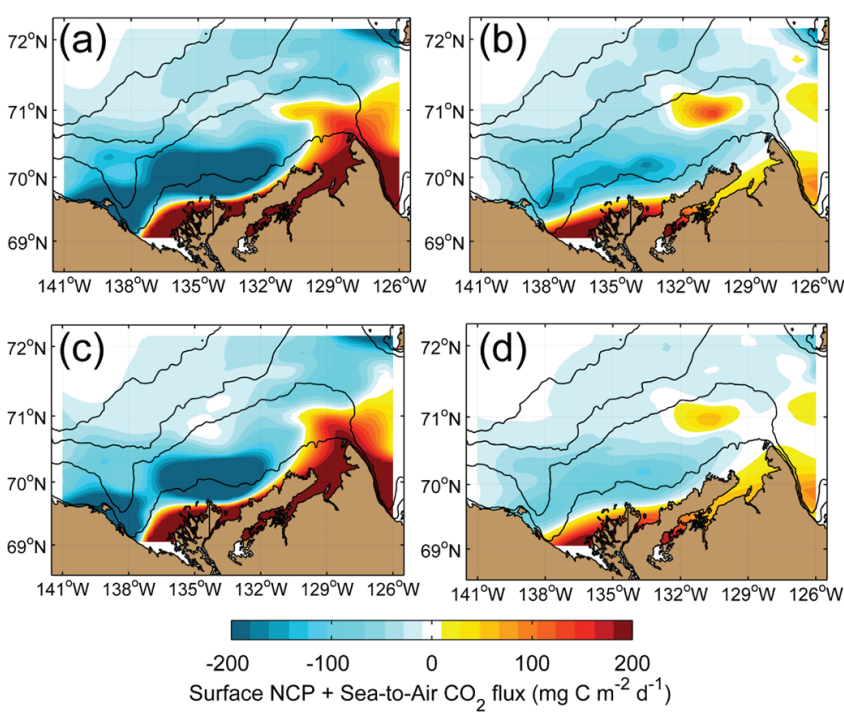

Figure A1. Results of a sensitivity analysis conducted on NCP and $\mathrm{CO}_{2}$ flux estimates. As in Fig. 12, the positive values here mean that the potential for $\mathrm{CO}_{2}$ sink due to a positive NCP was dampened by external forcings, while negative values mean that the potential for $\mathrm{CO}_{2}$ source due to negative NCP (net heterotrophy) was compensated by factors that lowered $p \mathrm{CO}_{2} \mathrm{SW}$ (e.g., cooling, dilution, inherent low $p \mathrm{CO}_{2}$ owed to past photosynthesis). Maps were constructed using the range of possible NCP and $\mathrm{CO}_{2}$ flux $\left(F \mathrm{CO}_{2}\right)$ values as based on the error associated with each variable. (a) $\left(F \mathrm{CO}_{2}+30 \%\right)+(\mathrm{NCP}+75 \%)$; (b) $\left(F \mathrm{CO}_{2}+\right.$ $30 \%)+(\mathrm{NCP}-75 \%) ;(\mathbf{c})\left(F \mathrm{CO}_{2}-30 \%\right)+(\mathrm{NCP}+75 \%)$; and $(\mathbf{d})$ $\left(F \mathrm{CO}_{2}-30 \%\right)+(\mathrm{NCP}-75 \%)$. See Appendix A for further details.

proach that combined data set from various sources to provide our best estimate of ecosystem functioning.

With the aim of exploring the impact of the uncertainty associated to our results on our conclusions, we provide here a simple sensitivity analysis. This exercise makes use of the end values within the range of possible estimates as derived from the combination of an error of $\pm 30 \%$ for $\mathrm{CO}_{2}$ fluxes and $\pm 75 \%$ for NCP. The results of this boundary-value analysis are presented in Fig. A1. This figure is divided into four panels, which respectively represent the addition of surface $\mathrm{NCP}$ and $\mathrm{CO}_{2}$ fluxes $\left(F \mathrm{CO}_{2}\right)$ as in Fig. 12, but for

1. $\left(\mathrm{FCO}_{2}+30 \%\right)+(\mathrm{NCP}+75 \%)$

2. $\left(F \mathrm{CO}_{2}+30 \%\right)+(\mathrm{NCP}-75 \%)$

3. $\left(\mathrm{FCO}_{2}-30 \%\right)+(\mathrm{NCP}+75 \%)$

4. $\left(\mathrm{FCO}_{2}-30 \%\right)+(\mathrm{NCP}-75 \%)$. 
As in Fig. 12, the positive values mean that the potential for $\mathrm{CO}_{2}$ sink due to a positive NCP was dampened by external forcings (e.g., upwelling of $\mathrm{CO}_{2}$-rich waters, warming/evaporation, photomineralization), while negative values mean that the potential for $\mathrm{CO}_{2}$ source due to negative $\mathrm{NCP}$ (net heterotrophy) was compensated by factors that lowered $p \mathrm{CO}_{2} \mathrm{SW}$ (e.g., cooling, dilution, inherently low $p \mathrm{CO}_{2}$ owed to past photosynthesis). This analysis shows that even if the absolute numbers varied as a result of the possible range of values (Fig. A1), the spatial pattern was very similar to the mean result as presented in Fig. 12. In brief, the conclusions reached in Sects. 4 and 5 on the basis of our $\mathrm{CO}_{2}$ flux and $\mathrm{NCP}$ assessments remain valid. 